\title{
A Dynamic Model of Corporate Financing with Market Timing
}

\author{
Baozhong Yang ${ }^{1}$ \\ Graduate School of Business \\ Stanford University
}

First Draft: September, 2007

This Draft: January, 2008

\section{** Job Market Paper **}

\begin{abstract}
In this paper, I consider a dynamic trade-off model of financing with difference in beliefs between the manager and investors. In the model, investors update more readily on earnings announcements than the manager does. The model offers a parsimonious treatment of endogenous financing, payout, and cash policies. The model generates a broad set of well-documented empirical facts that are difficult to explain using standard theories. In particular, the model predicts: 1) high stock returns predicting equity issuance, 2) the low debt ratios of firms in crosssection, 3) the substantial presence of firms with no debt or negative net debt and the fact that zero-debt firms are more profitable, pay larger dividends, and keep higher cash balances than other firms, and 4) the negative relationship between profitability and both book and market leverage ratios. If investors overextrapolate trends in earnings growth, the model also predicts the negative/positive long-run abnormal returns following stock issuances/repurchases.
\end{abstract}

\footnotetext{
${ }^{1}$ I am indebted to Ilya Strebulaev, and Peter Demarzo for continuous guidance and encouragement. I am grateful to Darrell Duffie, Paul Pfleiderer, and Jeff Zwiebel for many insightful discussions. I would also like to thank Snehal Banerjee, Dirk Jenter, Stefan Nagel, Paul Povel and seminar participants at University of Minnesota (Carlson), and Stanford University for helpful comments. All remaining errors are mine. Email: yang_baozhong@gsb.stanford.edu.
} 


\section{Introduction}

The idea that managers attempt to "time the market" and take advantage of (possibly perceived) mispricing of their firms' securities through corporate financing activities has been proposed to explain many empirical facts that are otherwise difficult to square with the rational expectations framework. ${ }^{1}$ Graham and Harvey (2001), Jenter (2005), and Jenter, Lewellen, and Warner (2007) provide survey and empirical evidence that managers attempt to time the market in their corporate financing activities. Despite its intuitiveness and potentially large impact on corporate financing, there has been a lack of theoretical models that formalize the market timing hypothesis and examine its implications. ${ }^{2}$

In this paper, I build a dynamic trade-off model of corporate financing with difference in beliefs between the manager and investors. The model offers a parsimonious treatment of endogenous external financing, payout, and cash policies. I show that the market timing behavior by managers produces a much broader set of empirical predictions than generally associated with market timing. In particular, market timing leads to a number of well-documented stylized facts about the crosssectional properties of corporate leverage.

The model deviates from the rational expectations framework in that the manager and investors' beliefs differ from each other. In the model, when investors form their beliefs, they put more weight on the most recent earnings announcement than the manager does. There are two main scenarios to consider here. In the first scenario, the manager knows the true underlying model of earnings, while investors don't. Rather, investors form their beliefs about the firm's earnings growth prospects based on the history of earnings, by using a weighted average of recent and past realized earnings to derive the new estimate of earnings. What makes these investors different from rational agents is that the weight they assign to new information is greater than the rational Bayesian weight. This deviation from full rationality is motivated by the representativeness heuristic and the hot-hand fallacy, experimentally and empirically supported by a large literature in psychology and finance. ${ }^{3}$ In the second scenario of the model, investors use the same updating model but are correct with

\footnotetext{
${ }^{1}$ See Section 2.1 for a detailed discussion of the empirical literature related to market timing.

${ }^{2}$ Shleifer and Vishny (2003) propose a model of market timing in merger and acquisition activities.

${ }^{3}$ See for example, Tversky and Kahneman (1974), Gilovich, Vallone, and Tversky (1985), De Bondt (1993), Bolger and Harvey (1993), Bloomfield and Hale (2002), Muradoglu (2002), and Johnson and Tellis (2005), and Lakonishok, Shleifer, and Vishny (1994). See Section 2.2 for a more detailed discussion of this literature.
} 
their model and the manager is erroneous in believing that he has the correct model. In the rest of this introduction, I will present the predictions based on the first scenario. However, it is important to note that all of the model's predictions, except for the results on long-run abnormal returns, hold for both scenarios and thus depend only on the difference of opinions between the manager and investors, and not on the irrationality of either parties.

In the solution of the model, the manager exhibits market timing behavior in that his optimal financial policies depend on the difference between his and investors' beliefs. To understand the results of the model, one basic intuition is that stock prices are much more sensitive to market misvaluation than bond prices are. Therefore, when investors' beliefs are high, the manager issues equity, to reap the greatest benefits of market timing, and retires debt or increase cash balances, to balance the budget. As a result, the firm decreases leverage when it is overvalued. Similarly, when investors' beliefs are low and the firm is undervalued, the manager repurchases equity, issues debt, reduces cash holdings, and thus increases leverage.

I first examine the model's predictions that are usually associated with the market timing hypothesis. The model predicts that firms with higher prior one-year stock returns or higher marketto-book ratios are more likely to issue equity, consistent with empirical evidence. ${ }^{4}$ Intuitively, higher prior stock returns and higher market-to-book ratios are associated with higher investors' beliefs and a greater probability that the stock is overpriced, leading the manager to issue equity to exploit the overvaluation.

The model also predicts that leverage-decreasing activities, i.e., equity issuance, debt reduction, and increases in cash balances, are followed by negative long-run abnormal returns; leverageincreasing activities, i.e., equity repurchase, debt issuance, and decreases in cash balances, on the other hand, are followed by positive long-run abnormal returns. The intuition behind these results is that although investors may misvalue a firm temporarily, the market valuation reverses to correct levels in the long run. The predictions of long-run returns for equity issuances/repurchases are consistent with the empirical evidence ${ }^{5}$ and the other predictions can be used to test the market timing hypothesis.

\footnotetext{
${ }^{4}$ See, for example, Marsh (1982), Hovakimian, Opler, and Titman (2001), and Hovakimian, Hovakimian, Tehranian (2004).

${ }^{5}$ See, for example, Ritter (1991), Loughran and Ritter (1995), Spiess and Affleck-Graves (1995), and Ikenberry, Lakonishok, and Vermaelen (1995).
} 
There is a related theoretical literature that explain the relationship between equity financing and stock returns through different mechanisms. Lucas and McDonald (1990) proposes a model based on asymmetric information. Dittmar and Thakor (2007) suggests a model based on the degree of agreement between the manager and investors about investment projects. Pastor and Veronesi (2003), Carlson, Fisher, and Giammarino (2005), Li, Livdan, and Zhang (2006) build neoclassical models of corporate financing and investment. While these models explain the above stylized facts with different degrees of success, they are however less suited to explain the observed cross-sectional properties of corporate leverage, which I will examine below.

First, the model predicts the low average debt ratios of firms. Structural trade-off models usually produce higher leverage ratios than those in the empirical data. A benchmark financing model in Leland (1994) produces optimal leverage ratios as high as $70 \%$ to $90 \%$, compared, for example, to the empirical average market leverage ratio of $26 \%$ for US firms in COMPUSTAT over the period 1987-2003. A number of studies have been trying to identify theoretically the reasons why firms are on average low levered. ${ }^{6}$ This model identifies market timing as an important factor that can lead to lower leverage ratios. The intuition for the low debt ratios is that the effects of market timing on capital structure is asymmetric in the cases with high and low market valuations of the firm. The convexity of bankruptcy costs implies that it is more costly to increase leverage than to decrease leverage. Therefore, firms respond more to overpricing than to underpricing and have on average lower leverage ratios than in the benchmark case of a standard trade-off model.

Second, the model predicts the extreme debt conservatism of a substantial fraction of firms. Graham (2000) discovers that "paradoxically, large, liquid, profitable firms with low expected distress costs use debt conservatively" and leave significant amounts of potential tax benefits unused. Strebulaev and Yang (2007) find that about 10\% (over 30\%) of large US public firms have zero debt (negative net debt) over the period 1963-2002. In a simulated data set of my model, there are more than $10 \%$ of firm-year observations with negative net debt under the set of plausible parameters. Furthermore, the model predicts that zero-leverage firms are more profitable, pay larger dividends and higher taxes, and keep larger cash balances than other firms, consistent with evidence found in Strebulaev and Yang (2007).

The intuition of the substantial presence of firms with zero debt is that a period with consistent

\footnotetext{
${ }^{6}$ See for example, Goldstein, Ju, and Leland (2001), Morellec (2003), Ju, Parrino, Poteshman, and Weisbach (2005), and Strebulaev (2007).
} 
good earnings shocks can lead to many rounds of debt reductions or cash accumulations, creating firms with zero or negative net debt. Zero-leverage firms are more profitable because profitability proxies for investors' beliefs, which are high for these firms. Zero-leverage firms pay higher dividends because stock repurchases are more costly for them and cash holdings are costly due to the tax costs on interests earned. As the result of being more profitable and issuing more equity with no debt obligations to meet, the zero-leverage firms have a larger net cash inflow each period, and thus keep a larger cash balance.

Third, the model predicts the negative correlation between profitability and both the book and the market leverage ratios, a stylized fact documented in almost every empirical study of capital structure. $^{7}$ This fact was previously viewed as a major setback to the trade-off theory. Strebulaev (2007) explains the negative relationship between profitability and the market leverage through the infrequent adjustment of capital structure, within the trade-off framework. The intuition behind my model's prediction is that more profitable firms are more likely to issue equity and reduce debt, i.e., conduct an active policy in the opposite direction predicted by the standard trade-off theory, resulting in the negative correlation between profitability and both book and market leverage ratios. $^{8}$

My model is related to two branches of theoretical research. First, the model is related to the stream of theoretical research that explains anomalies in asset markets by models with boundedly rational investors. A partial list includes Barberis, Shleifer, and Vishny (1998), Hirshleifer, Daniel, and Subramanyam (1998), Hong and Stein (1999), Barberis, Huang, and Santos (2001), and Hong, Stein, and Yu (2006). Similar to these studies, my model is able to generate a rich set of predictions in a dynamic structural framework where investors only deviate from full rationality in simple ways consistent with psychological and experimental evidence. Second, the model is related to a large literature that study dynamic trade-off models and various extensions, including Fisher, Heinkel, and Zechner (1989), Leland (1994), Leland and Toft (1996), Leland (1998), Goldstein, Ju, and Leland (2001), Morellec (2003), Hennessy and Whited (2005), Ju, Parrino, Poteshman, and Weisbach (2005), Strebulaev (2007), Hennesy, Livdan, and Miranda (2007), and Titman and

\footnotetext{
${ }^{7}$ See, for example, Rajan and Zingales (1995) and Fama and French (2002).

${ }^{8}$ As there are also transaction costs of financing in my model, the mechanism noted in Strebulaev (2007) is also present in my model and causes a more significant negative correlation of profitability with market leverage than with book leverage, consistent with empirical evidence.
} 
Tsyplakov (2007). Similar to this literature, my model is concerned with explaining the dynamics of corporate leverage and more generally corporate financial policies.

The rest of this paper is organized as follows. Section 2 reviews empirical evidence supporting market timing behavior in corporate finance, and the psychological evidence that motivates the behavioral assumption in my model. Section 3 sets up the model. Section 4 describes the numerical solution of the model. Section 5 presents empirical implications of the model through simulation of the model. Section 6 provides further discussions. Section 7 concludes.

\section{Evidence for Market Timing and Extrapolation}

\subsection{Evidence for Market Timing}

This subsection summarizes evidence from different studies that have suggested market timing is an important consideration for corporate financing decisions.

Graham and Harvey (2001) survey CEOs and CFOs on corporate finance issues, and find that the level of stock prices is regarded as the most important factor, out of 10 factors considered, in managers' decision to issue common stock. Two-thirds of CFOs agree that "the amount by which our stock is undervalued or overvalued was an important or very important consideration" for equity issuance.

Some studies revealed that earnings realization after equity issuances often fall short of the forecasts before the issuances. ${ }^{9}$ This indicates that firms tend to issue equity when investors are too optimistic about earnings prospects. La Porta (1996) finds that stocks with the highest growth forecasts by analysts earn much lower future returns than stocks with the lowest growth forecasts, suggesting that even analysts do become overly optimistic or overly pessimistic over time, creating opportunities for market timing.

If managers are successful in issuing equity when the firm's stock is overvalued and market subsequently adjust back to the "rational" level, then equity-issuing firms should have lower returns than firms with comparable characteristics. This is the findings of Stigler (1964), Ritter (1991), Loughran and Ritter (1995), Speiss and Affleck-Graves (1995), and Brav and Gompers (1997), among others. On the other hand, Ikenberry, Lakonishok, and Vermaelen (1995) find that stock

\footnotetext{
${ }^{9}$ For example, see Loughran and Ritter (1997), Rajan and Servaes (1997), Teoh, Welch, and Wong (1998a, 1998b), and Dennis and Sarin (2001).
} 
repurchases subsequently have higher returns. It should be noted that the significance of these long-run returns has been an issue of debate. ${ }^{10}$ Pontiff and Woodgate (2006), in a recent work, using a new definition of equity issuance based on CRSP shares outstanding data, reconfirmed the results of long-run return studies, for a much larger sample. In the aggregate time-series data, Baker and Wurgler (2000) discover that if equity issuance is high in a given year, the market as a whole performs poorly in the next year. Baker and Wurgler (2002) document evidence consistent with the market timing of firms and argue that market-timing has a very persistent effect on capital structure. $^{11}$

More direct evidence on managers' market timing activities is provided in Jenter (2004), who finds that managers' personal trading are similar to the firm's financing decisions, and Jenter, Lewellen, and Warner (2007), who document that firms that sell put options earn positive abnormal return in the subsequent 100 days, supporting the hypothesis that managers have the ability to time the market.

\subsection{Psychological Evidence for Extrapolation}

In my model, one key assumption is that investors have the tendency to extrapolate on recent trends of earnings growth and put more weight on the recent earnings numbers than they should. This is motivated by the representative heuristic and the hot-hand fallacy, well-documented phenomena in psychology. There is a large literature on these behavioral biases. This subsection discusses the related experimental and empirical evidence.

Tversky and Kahneman (1974) document the representativeness heuristic, the tendency of people to overestimate the probability an observation belongs to a class by overweighting the salient properties of the observation that match the descriptions the class, while underweighting the small probability that the observation occurs in the population. This is closely related to the hot-hand fallacy. The term "hot hand" comes from the common belief of basketball fans and players that after a player makes a sequence of good shots in a game, the player have a better chance to keep on

\footnotetext{
${ }^{10}$ For example, see Fama (1998), and Schultz (2003).

${ }^{11} \mathrm{~A}$ later empirical literature, while confirms the short-term effects of market timing on capital structure, shows that firms adjusts leverage in the opposite direction afterwards, consistent with a trade-off model with transaction costs. See, for example, Alti (2006), Flannery and Rangan (2006), Huang and Ritter (2006), Kayhan and Titman (2006), and Leary and Roberts (2005).
} 
throwing good shots. However, Gilovich, Vallone, and Tversky (1985) show that statistically there is no correlation between the players' performance before and after. In this example, people actually use the representativeness heuristic to make predictions on the player's next shot by overweighting the fact that recent sequence of shots match a good pattern, while underweighting the fact that this sequence may simply arise randomly from a population. Similarly, when investors observe a consistently good history of earnings growth of a company, they assign a greater probability that the company will continue to grow at similar rates in the future, despite that such a sequence may simply arise out of luck.

De Bondt (1993) carry out experiments and surveys and find that people extrapolate past histories. In particular, people forecast greater changes in prices after observing a sequence of previous price increases than after price decreases. Bolger and Harvey (1993) document that people tend to use the value of the last observation in a sequence as an anchor to make predictions and usually put too large a weight on the last observation. Lakonishok, Shleifer, and Vishny (1994) show that investors rely on past information, such as earnings and sales growth, in their estimates of the value of stocks.

Bloomfield and Hales (2002) present participants with time series from random walks and find that MBA student investors use the recent rate of reversals in a sequence to predict the likelihood of future reversals, even though they are told very clearly that the sequence was a random walk and that future outcomes could not be reliably predicted from past outcomes. The striking finding that investors try to predict patterns even when they know that the sequence is a random walk suggests that this behavior comes from human nature.

Muradoglu (2002) employ professional fund managers as well as student subjects to forecast stock prices. A real-time, real-world scenario is created by using the real history of prices of specific stocks and indices (names and the time frames withheld from participants). Both experts and individuals extrapolate past trends in bull markets for both short (two-week) and long (twelveweek) horizons. The results for bear markets are more mixed: predictions of both continuations and reversals of trends occur for different groups and horizons.

Johnson and Tellis (2005) conduct experiments that ask student subjects to decide to buy or sell a stock after studying the past earnings history of the firm. The setup of this experiment is very close to that of my main model. They find that participants initially extrapolate from past run of earnings and adopt momentum strategies, for runs of short to intermediate lengths. For 
very long runs, the individuals reverse their decisions and use contrarian strategies. Through an empirical study of S\&P 500 indexed firms, they also show that firms have abnormal returns that increase with the length of runs in their earnings, at least for positive runs.

In summary, there is strong experimental and empirical evidence supporting investors' tendency to extrapolate from recent trends, especially for positive trends. It will become clear later that the results of this work mainly depend on investors' extrapolation of positive trends, and thus rest on a robust behavioral pattern.

\section{The Model}

\subsection{The Economy and Agents}

In the economy, events happen in discrete periods, denoted by $t=1,2, \ldots$ Investors in the economy are risk-neutral and have a discount rate $\beta=1 /(1+r)$. There is a risk-free asset in the economy with a constant risk-free rate of $r$. A firm generates cash flow $N_{t}$ in period $t$. The earnings $N_{t}$ follow the following process,

$$
N_{t}=N_{t-1}\left(1+y_{t}\right)
$$

where $y_{t}$ is the shock to the earnings growth rate in period $t$. In each period, $y_{t}$ takes two possible values, $y>0$ with probability $p_{0}$, or $-y$ with probability $1-p_{0}$. The value of the shock is publicly observable once it is realized in each period and unobservable to all before its realization. The firm's mean growth rate of earnings is equal to $\left(2 p_{0}-1\right) y$.

The operations of the firm are controlled by a manager who is initially endowed with a fixed number of shares of the firm's stock. The manager has the same preferences as the investors, and has perfect knowledge of the persistence parameter $p_{0}$. As an insider, the manager is restricted from selling or buying the firm's stock. The manager's objective is to maximize the expected present value of the dividend stream to which he is entitled as a shareholder. ${ }^{12}$

While the manager observes $p_{0}$, the process that generates $y_{t}$ and $N_{t}$ is unknown to the investors, nor are the investors aware of the manager's knowledge of it. Instead, investors update their beliefs about the earnings process based on the firm's earnings history. Define $q_{t-1} \in[0,1]$ as the probability that the investor assign to a good event happening (i.e. $y_{t}=y$ ), just before the earnings

\footnotetext{
${ }^{12}$ This assumption on the manager's objective function is the equivalent to the assumption that the manager maximizes long-term shareholders' welfare, such as in Myers and Majluf (1984).
} 
announcement in period $t$. Investors use a simple heuristic updating model to revise their beliefs after earnings are announced,

$$
q_{t}=\rho \mathbf{1}_{y_{t}=y}+(1-\rho) q_{t-1} .
$$

In formula (2), investors use a weighted average of new information and the past estimate to come up with a new estimate. The parameter $\rho$ is the weight investors assign to the new information contained in the shock $y_{t}$. Note that if investors are fully rational and know that the parameter $p_{0}$ is a constant, even though they do not know the value of $p_{0}$, they will use rational Bayesian updating to estimate $p_{0}$. The rational Bayesian updating formula is

$$
q_{t}^{R}=\frac{1}{t} \mathbf{1}_{y_{t}=y}+\frac{t-1}{t} q_{t-1}^{R},
$$

assuming that the investors have a uniform prior before period 1. The Bayesian updating formula (3) is similar to (2), except that the weight on new information, i.e. $\frac{1}{t}$, decreases with time $t$ and converges to zero as $t$ goes to infinity, as learning becomes less and less informative. Instead, (2) suggests that investors place a constant weight on newly arrived information, giving usually greater importance to new information that it really deserves. ${ }^{13}$ In essence, it formalizes in a simple and intuitive way the motivation of the representativeness heuristic or hot-hand fallacy, discussed in Section 2.2. By emphasizing new information over stale information, investors tend to overextrapolate the current trend in earnings growth into the future, and thus obtain a biased estimate of the firm's value.

Investors' belief formation process is common knowledge. Therefore, the manager is fully aware of investors' tendency to over-extrapolate from recent histories of earnings growth, and he will take advantage of this through the firm's financing decisions.

\subsection{Financial Decisions of the Firm}

In the model, the manager's decision consists of several dimensions: the timing and amount of issuing/repurchasing equity, issuing/retiring debt, adjusting cash balances, and deciding on the dividend stream. When secondary equity offer is conducted, investors first adjust their valuation of the firm, and then purchase shares at the adjusted price. ${ }^{14}$ While I assume risk-neutrality for

\footnotetext{
${ }^{13}$ In this paper, the emphasis is put on the properties of the steady state optimal financing policies, and thus $t$ can be regarded as large and it can be assumed that $\rho>\frac{1}{t}$.

${ }^{14}$ As all investors hold the same belief in the model, it is not essential whether existing shareholders or new investors purchase the new shares.
} 
simplicity, stock prices are not fully elastic. In particular, I assume that there are temporary liquidity effects of equity issuance and repurchases on stock prices, which are proportional to the number of shares offered/repurchased as a fraction of outstanding shares. This assumption reflects the effect of demand and supply on equity prices, similar to a general equilibrium model with risk-averse agents.

Since the manager is constrained from buying new shares or selling his own shares, the manager prefers to issue new shares when prices are higher than the intrinsic value of the stock and repurchase shares when prices are lower, thus reaping benefits by partially arbitraging the mispricing of equity.

Corporate debt is assumed to be perpetual, similar to Leland $(1994,1998)$. Debt is callable at any time with a coupon rate of $r$, the risk-free rate; in other words, debt with coupon $c$ outstanding can be called at $c / r .{ }^{15}$ Debt is fairly priced by investors when issued, and thus since default may happen, debt is issued below par value to reflect the risk of default. To issue new debt, all outstanding debt needs to be recalled. ${ }^{16}$ Although the manager decides on the timing and amount of debt issuance, equityholders decide when the firm defaults, since in financial distress, shareholders provide additional funding to cover debt payment, and whether shareholders are willing to provide more money hinges on their own valuation of the firm. ${ }^{17}$ The time of default is thus the first time the market value of equity drops to zero. Upon default, the firm is liquidated and debtholders recover a fraction $\lambda<1$ of the unlevered firm value (i.e., the continuation value of the firm if it keeps on operating with zero debt.) These bankruptcy costs of debt reflect, e.g., legal and negotiation costs, loss of human capital, missed investment opportunities, and damage to relationships with customers and suppliers. Corporate tax rate is assumed to be a constant $\tau$ and coupon payments on corporate debt are tax-exempt. Therefore, debt has a tax benefit over equity financing. ${ }^{18}$

Equity issuance is costly. If $I_{E}$ is the issuance amount of equity, then the transaction cost of

\footnotetext{
${ }^{15}$ The assumption that debt is called at the price of risk-free debt is for simplicity, as otherwise there will be an additional state variable for the face value of debt in the model. This assumption also reflects a premium usually associated with early retirement of debt.

${ }^{16}$ This is a standard assumption made to avoid the complication of considering seniority of debt, similar to Leland (1994, 1998).

${ }^{17}$ Although this assumption is more realistic, assuming instead that the manager makes the default decision does not affect the results qualitatively. Despite that the manager is also a shareholder, it is assumed that outside investors hold the majority of shares and make the default decision.

${ }^{18}$ The results and intuition do not depend on the existence of tax benefits of debt. In a model without tax benefits for debt, all the qualitative results still obtain, but with lower equilibrium levels of debt.
} 
issuance is given by

$$
\operatorname{Cost}\left(I_{E}\right)=c_{1}^{E} I_{E} \mathbf{1}_{I_{E}>0}, \quad \text { with } c_{1}^{E}>0
$$

The proportional cost is assumed to be non-existent for equity repurchases, debt issuances, or debt retirements. $^{19}$

In the model the manager also decides on the firm's cash policy. As interest income on cash holdings is taxed at the corporate tax rate, cash can be regarded as equivalent to negative debt. Therefore, for simplicity, I use a single variable $b_{t}$ to represent the face value of debt (if $b_{t}>0$ ) or the cash balance of the firm (equal to $-b_{t}$ if $b_{t}<0$ ). ${ }^{20}$ The variable $c_{t}=r b_{t}$ then represents the required coupon payment of the firm (if $c_{t}>0$ ) or the interest income from cash holdings of the firm (if $c_{t}<0$, in this case the interest income is $-c_{t}$ ). The firm's after-tax net income is then given by the formula $(1-\tau)\left(N_{t}-c_{t}\right)$, where $c_{t}$ can be either positive or negative.

Finally, the manager decides on the payout policy. Firms are assumed to not pay dividends more than its net income, i.e.

$$
\operatorname{Div}_{t} \leq(1-\tau)\left(N_{t}-c_{t}\right)
$$

Thus, I exclude one-time extraordinary dividends from the consideration. Intuitively, firms have dividend-smoothing incentives, and thus do not want to distribute too much dividends in one period, knowing that it has to cut it back later.

\subsection{Timeline of the Model}

The timeline of the model is drawn in Figure 1 and detailed below.

- At the start of period $t$, investors have belief $q_{t-1}$ about the state of the world and value the firm according to this belief. The firm has debt outstanding with coupon payment $c_{t}$ if $c_{t}>0$, or a cash balance of $\left|c_{t}\right| / r$ if $c_{t}<0$.

\footnotetext{
${ }^{19}$ The assumption that only equity issuance is costly is made for simplicity, and to reflect the fact that the other financing activities usually come with transaction costs much smaller than those of equity issuances. Assuming nonzero costs for these activities does not affect any results of this paper qualitatively.

${ }^{20}$ Under this assumption, the firm either has zero debt or zero cash holdings. Such an assumption is used, for example, in Hennessy and Whited (2005), and Hennessy, Livdan, and Miranda (2007). Allowing both debt and cash as independent variables will increase the number of state variables and complicates the computation greatly, and is unlikely to change the main qualitative results.
} 
- The profit $N_{t}=N_{t-1}\left(1+y_{t}\right)$ is realized. Investors use the shock $y_{t}$ to update their belief to $q_{t}$ and the market prices of equity and debt are adjusted accordingly.

- If the price of equity drops to zero, equity holders default on the coupon payment and the firm is liquidated.

- If the firm does not default, the manager decides on equity issuance $I_{E, t}$ (repurchase if $<0$ ), debt issuance $I_{D, t}$ (reduction if $\left.<0\right)$, and dividend payment Div . The decisions satisfy the following budget balancing condition:

$$
(1-\tau)\left(N_{t}-c_{t}\right)+I_{E, t}+I_{D, t}-\operatorname{Cost}\left(I_{E, t}, I_{D, t}\right)-D i v_{t}=0
$$

- Stock and bond prices are adjusted when the firm announces its financing, cash, and dividend plans.

- Period $t+1$ starts.

\subsection{Valuation of Equity and Debt}

The state of the economy in each period, after earnings realization, can be summarized by three state variables: $N_{t}$, the operating income of the firm, $q_{t}$, investors' belief about the firm's earnings growth prospect, and $c_{t}$, the interest payment of outstanding debt. I will denote the value of equity and debt based on investors' beliefs (thus the market values) by $V_{t}^{I}\left(N_{t}, q_{t}, c_{t}\right)$ and $D_{t}^{I}\left(N_{t}, q_{t}, c_{t}\right)$, and the value of equity and debt based on the manager's belief by $V_{t}^{M}\left(N_{t}, q_{t}, c_{t}\right)$ and $D_{t}^{M}\left(N_{t}, q_{t}, c_{t}\right)$. All of these value functions refer to values just after earnings realization and before financing decisions in period $t$.

Denote by $M_{t}$ the total number of outstanding shares of the firm in period $t$. The manager's valuation of equity in period $t$ is given by

$$
V_{t}^{M}\left(N_{t}, q_{t}, c_{t}\right)=M_{t} \sum_{s=t}^{\infty} \beta^{s-t} E_{t}\left[\frac{D i v_{s}}{M_{s}} \mathbf{1}_{T_{B}>s}\right],
$$

where $\beta=1 /(1+r)$ is the discount rate of risk-neutral investors, $E_{t}[\cdot]$ is the period- $t$ expectation operator, and $T_{B}$ is the time of default. There is no liquidation payoff to shareholders as the price of equity at default is zero. To derive the market value of equity, I denote by $M_{s}^{I}$ the investors' belief about the number of outstanding shares in period $s$. Similarly, to denote investors' beliefs 
formed in period $t$ about other parameters, the superscript $I$ will be used. The investors' valuation of equity of the firm in period $t$ is given by

$$
V_{t}^{I}\left(N_{t}, q_{t}, c_{t}\right)=M_{t} \sum_{s=t}^{\infty} \beta^{s-t} E_{t}^{I}\left[\frac{D i v_{s}^{I}}{M_{s}^{I}} \mathbf{1}_{T_{B}^{I}>s}\right]
$$

Similarly, the value of debt based on the manager's belief in period $t$ is

$$
\begin{array}{r}
D_{t}^{M}\left(N_{t}, q_{t}, c_{t}\right)=\sum_{s=t}^{\infty} \beta^{s-t} E_{t}\left[c_{t} \mathbf{1}_{\min \left(T_{B}, T_{R}^{t}\right)>s}+c_{t}\left(1+\frac{1}{r}\right) \mathbf{1}_{T_{R}^{t}=s<T_{B}}\right. \\
\left.+\min \left(\lambda V_{s}^{I}\left(N_{s}, q_{s}, 0\right), c_{t}\left(1+\frac{1}{r}\right)\right) \mathbf{1}_{T_{B}=s<T_{R}^{t}}\right]
\end{array}
$$

where $T_{R}^{t}$ is the time of retirement of existing debt in period $t$ (recall that when new debt is issued, old debt is retired), and $T_{B}$ is the time of default. ${ }^{21}$ The first term in the argument of the expectation operator in (7) is the coupon payment received by current debt holders if the firm does not default and debt is not retired in period $s$. The second term is the full retirement value received by debtholders, i.e., the principal plus interest, when debt is retired in period $s$ (for example, when new debt is issued). By assumption, the principal, or the face value of debt, is $c_{t} / r$. The third term is the recovery value of debt upon default. Note that in liquidation, debt holders recover a fraction $\lambda$ of the market value $V_{s}^{I}$, rather than of the intrinsic value $V_{s}^{M}$. Similarly, investors' valuation of debt is given by

$$
\begin{aligned}
D_{t}^{I}\left(N_{t}, q_{t}, c_{t}\right)=\sum_{s=}^{\infty} & \beta^{s-t} E_{t}^{I}\left[c_{t} \mathbf{1}_{\min \left(T_{B}^{I}, T_{R}^{I}\right)>s}+c_{t}\left(1+\frac{1}{r}\right) \mathbf{1}_{T_{R}^{I}=s<T_{B}^{I}}\right. \\
& \left.+\min \left(\lambda V_{s}^{I}\left(N_{s}^{I}, q_{s}^{I}, 0\right), c_{t}\left(1+\frac{1}{r}\right)\right) \mathbf{1}_{T_{B}^{I}=s<T_{R}^{I}}\right] .
\end{aligned}
$$

It is a standard practice of dynamic programming to represent value functions in a recursive form. The recursive equations are easier to analyze qualitatively, or solve numerically. Below I derive the recursive forms of the equity and debt value functions, defined in (5) - (8). First, it is easy to rewrite (5) as

$$
V_{t}^{M}\left(N_{t}, q_{t}, c_{t}\right)=\frac{M_{t}}{M_{t+1}}\left(D_{i v_{t}}+\beta E_{t}\left[V_{t+1}^{M}\left(N_{t+1}, q_{t+1}, c_{t+1}\right) \mid N_{t}, q_{t}, c_{t}\right]\right) \mathbf{1}_{T_{B}>t} .
$$

\footnotetext{
${ }^{21}$ This is actually a simplified case that does not consider the possibility that a fraction of debt may be retired pro rata in any period. Allowing that possibility will make the expression more cumbersome. Using the recursive formula below, however, it is rather easy to incorporate such cases.
} 
The variables $\frac{M_{t}}{M_{t+1}}, D i v_{t}$, and $c_{t}$ are components of the manager's financial decision. Thus, (9) can be expanded to the following recursive optimization problem,

$$
\begin{gathered}
V_{t}^{M}\left(N_{t}, q_{t}, c_{t}\right)=\max _{a, D i v, c}(1-a)\left(\operatorname{Div}+\beta E_{t}\left[V_{t+1}^{M}\left(N_{t+1}, q_{t+1}, c\right) \mid N_{t}, q_{t}\right]\right) \mathbf{1}_{T_{B}>t} \\
\text { s.t. } \quad I_{E}=a\left(D i v+\beta \bar{V}_{t+1}^{I}(c)\right)\left(1-c_{2}^{E} \frac{I_{E}}{D i v+\beta \bar{V}_{t+1}^{I}(c)}\right), \quad a \leq 1 \\
I_{D}= \begin{cases}\beta \bar{D}_{t+1}^{I}(c)-\frac{c_{t}}{r}, \text { if } c>c_{t} \text { and } c>0 \\
\frac{c-c_{t}}{r}, & \text { if } c \leq c_{t} \text { or } c<0\end{cases} \\
(1-\tau)\left(N_{t}-c_{t}\right)+I_{E}+I_{D}-\operatorname{Cost}\left(I_{E}, I_{D}\right)-\operatorname{Div}=0
\end{gathered}
$$

Here $\bar{V}_{t+1}^{I}(c)$ and $\bar{D}_{t+1}^{I}(c)$ are abbreviations for the continuation values of equity and debt as estimated by the investors, i.e., $E_{t}^{I}\left[V_{t+1}^{I}\left(N_{t+1}, q_{t+1}, c\right) \mid N_{t}, q_{t}\right]$ and $E_{t}^{I}\left[D_{t+1}^{I}\left(N_{t+1}, q_{t+1}, c\right) \mid N_{t}, q_{t}\right]$, respectively. The choice variable $a$ in the optimization problem represents the fraction of the claim to current and future cash flows of the firm offered to new shareholders if $a>0$, or the fraction repurchased if $a<0$. Note that $\frac{M_{t}}{M_{t+1}}=1-a^{*}$ for the optimal $a^{*}$. Equation (11) means that the new shareholders (or exiting shareholders in the case of repurchases) get a fair fraction of the firm ( $I_{E}$ on the left hand side is the amount of money raised, and the expression on the right hand side is the fair market value of equity.) The term $c_{2}^{E} \frac{I_{E}}{D i v+\beta V_{t+1}^{I}(c)}$ represents the market impact on stock prices of equity issuances/repurchases, which is linear in ratio of the amount of issuance/repurchase relative to the total value of equity.

The choice variable $c$ is the new coupon level, and $c_{t+1}=c^{*}$, for the optimal $c^{*}$. Equation (12) represents the break-even condition for new bond holders. In the first case of (12), when $c>c_{t}$ and $c>0$, new debt is issued and old debt is retired (or cash balances are reduced if $c_{t}<0$ ). The impact of retirement of debt and reduction in cash to the firm's balance sheet are expressed by the same amount $\frac{c_{t}}{r}$, and $\beta \bar{D}_{t+1}^{I}(c)$ represents the money the firm can raise from investors by increasing debt coupon level to $c$. Therefore, $\beta \bar{D}_{t+1}^{I}(c)-\frac{c_{t}}{r}$ represents the net money raised from the debt financing action. In the second case of (12), when $c \leq c_{t}$ or $c<0$, the firm is retiring part or all of its debt pro rata by face value and possibly increasing its cash balances. The net impact of these actions on the firm's balance sheet is given by $\frac{c-c_{t}}{r}$.

Equation (13) is the budget balancing condition for the firm, i.e., a replication of equation (4). It relates the decision on dividend payout to the financing actions $I_{E}$ and $I_{D}$.

Similarly, the investors' value function of equity can be written as the solution to the following 
recursive optimization problem,

$$
\begin{aligned}
& V_{t}^{I}\left(N_{t}, q_{t}, c_{t}\right)=\max _{a, D i v, c, T_{B}}(1-a)\left(D i v+\beta E_{t}^{I}\left[V_{t+1}^{I}\left(N_{t+1}, q_{t+1}, c\right) \mid N_{t}, q_{t}\right]\right) \mathbf{1}_{T_{B}>t} \\
& \text { s.t. } \quad I_{E}=a\left(D i v+\beta \bar{V}_{t+1}^{I}(c)\right)\left(1-c_{2}^{E} \frac{I_{E}}{D i v+\beta \bar{V}_{t+1}^{I}(c)}\right), \quad a \leq 1 \\
& I_{D}=\left\{\begin{array}{l}
\beta \bar{D}_{t+1}^{I}(c)-\frac{c_{t}}{r}, \text { if } c>c_{t} \text { and } c>0 \\
\frac{c-c_{t}}{r}, \quad \text { if } c \leq c_{t} \text { or } c<0
\end{array}\right. \\
& (1-\tau)\left(N_{t}-c_{t}\right)+I_{E}+I_{D}-\operatorname{Cost}\left(I_{E}, I_{D}\right)-\operatorname{Div}=0
\end{aligned}
$$

Here investors also need to decide whether to default, i.e., whether $T_{B}=t .{ }^{22}$ The decision is simple: the firm defaults if and only if the continuation value of equity is nonpositive. The continuation value of equity is just the maximum value of the optimization problem (14) without the $\mathbf{1}_{T_{B}>t}$ term.

As the new debt levels and cash balances are determined by (10) and (14), the recursive equations for debt can then be written as follows,

$$
\begin{aligned}
D_{t}^{M}\left(N_{t}, q_{t}, c_{t}\right) & =\left(c_{t}+\frac{c_{t}-c_{t+1}}{r}\right) \mathbf{1}_{T_{B}>t, c_{t+1} \leq c_{t}}+\beta E_{t}\left[D_{t+1}^{M}\left(N_{t+1}, q_{t+1}, c_{t+1}\right) \mid N_{t}, q_{t}, c_{t}\right] \mathbf{1}_{T_{B}>t, c_{t+1} \leq c_{t}} \\
& +c_{t}\left(1+\frac{1}{r}\right) \mathbf{1}_{T_{B}>t, c_{t+1}>c_{t}}+\min \left(\lambda \beta \bar{V}_{t}^{I}\left(N_{t+1}, q_{t+1}, 0\right), c_{t}\left(1+\frac{1}{r}\right)\right) \mathbf{1}_{T_{B}=t} .
\end{aligned}
$$

The first term on the right hand side of (18) is the interest payment plus any partial retirement of debt received by the debtholders. Note that $c_{t} \geq 0$ here, otherwise the firm has positive cash balances and no debt is outstanding. The second term is the expected future payment to existing debtholders after possibly partial retirement in this period. The third term refers to the full retirement value of existing debt when new debt is issued. The fourth term gives the recovery value of debt upon bankruptcy. Similarly, the investors' valuation of debt is given by

$$
\begin{aligned}
D_{t}^{I}\left(N_{t}, q_{t}, c_{t}\right) & =\left(c_{t}+\frac{c_{t}-c_{t+1}}{r}\right) \mathbf{1}_{T_{B}>t, c_{t+1} \leq c_{t}}+\beta E_{t}\left[D_{t+1}^{I}\left(N_{t+1}, q_{t+1}, c_{t+1}\right) \mid N_{t}, q_{t}, c_{t}\right] \mathbf{1}_{T_{B}>t, c_{t+1} \leq c_{t}} \\
& +c_{t}\left(1+\frac{1}{r}\right) \mathbf{1}_{T_{B}>t, c_{t+1}>c_{t}}+\min \left(\lambda \beta \bar{V}_{t}^{I}\left(N_{t+1}, q_{t+1}, 0\right), c_{t}\left(1+\frac{1}{r}\right)\right) \mathbf{1}_{T_{B}=t .}
\end{aligned}
$$

\footnotetext{
${ }^{22}$ For simplicity, I put down the default time $T_{B}$ as the choice variable with a little abuse of notation. The investors actually only decide whether $T_{B}=t$ or $T_{B}>t$, but not the exact value of $T_{B}$ in the latter case.
} 


\section{Numerical Solution of the Model}

The model contains three continuous state variables: the earnings level $N_{t}$, the investor's belief $q_{t}$, and the coupon level $c_{t}$, and there is no closed-form solution. Therefore, I resort to numerical methods to find the optimal financing policies and the value functions of debt and equity. Details of the numerical procedure are provided in the Appendix.

\subsection{Choice of Parameters}

This section describes how parameters in the model are chosen. When feasible, the parameters are chosen based on the empirical literature. The base case parameters of the model are reported in Table 1.

The average size of shock to earnings growth is set to $y=5 \%$. The risk-free rate, or the discount rate for the firm's cash flows, is set to be $r=10 \%$. The effective corporate tax rate is set to $\tau=20 \%$, the same as in Leland (1998). This choice reflects the reduction in tax benefits of a $35 \%$ corporate tax rate by the differential personal tax rates on interest income, capital gains, and dividends. The bankruptcy recovery rate is set to be $\lambda=0.8$, which falls in the range of estimates in Andrade and Kaplan (1998), and similar to the choice 0.75 in Leland (1998).

The probability of a good shock is set to $p_{0}=0.5$. Thus the firm has an average growth rate of zero, and its earnings process is a random walk. Investors' weight on new information is set to $\rho=0.1$. In other words, the rate of decay of the influence of information is $1-\rho=0.9$. With this choice, the influence of one period's earnings on investors' sentiment decreases by half in every $\log (0.5) / \log (0.9)=6.6$ years, and about two-thirds of today's investor's sentiment comes from the most recent 10 years of earnings history.

Altinkilic and Hansen (2000) estimate an average issuance cost of 5.38\% from common stock offers from 1990 to 1997. Gomes (2001) estimates a fixed cost of $8 \%$ and a proportional cost of $2.5 \%$, from a dataset from 1971 to 1975 . There is no fixed cost in this model, and the linear coefficient of equity issuance costs is chosen to be $c_{1}^{E}=5 \%$.

The coefficient $c_{2}^{E}$ of the variable cost of equity issuance/repurchase is set to 0.2 . This implies that an equity issuance of $15 \%$ of the firm's existing shares (the average equity issuance size in Mikkelson and Partch (1986)) would give rise to an impact of $0.15 \times 0.2=3 \%$, about the average price impact of common stock offers estimated in Mikkelson and Partch (1986) and other empirical 
studies.

\subsection{Properties of the Solution}

In studying the solution of the model, it might be most interesting to understand how the firm's financing policies depend on the investor sentiment $q$, keeping other variables fixed. Figure 2 and Figure 3 report the optimal financial policies for the firm, conditional on a high investor sentiment of $q=0.8$, and a low sentiment of $q=0.2$, respectively. ${ }^{23}$ To identify the incremental effects of market timing over and above other factors in the model, I also display the optimal financial policies for a benchmark model in both figures. In the benchmark model, there is no asymmetric information, investors and the manager both know the correct model of earnings, and other things are the same as in the main model. Thus, the benchmark model is a dynamic trade-off model with costs of financing. To further distinguish the effects of financing costs from those of other factors in the model, I display the optimal policies for a second benchmark model, in which costs of financing are absent. In other words, the second benchmark model is a standard trade-off model without transaction costs.

Panel A of Figure 2 and Figure 3 plot the leverage policy functions, i.e., the market leverage after financing as a function of that before financing, for the main model (conditional on $q=0.8$, and $q=0.2$, respectively) and the benchmark models. Negative leverage in the figure means that the firm has positive cash holdings and no debt outstanding. The leverage policy function determines how the firm's leverage would evolve dynamically and helps to understand whether the firm has a target leverage. To understand how the firm actually achieves the changes prescribed in the leverage policy functions, Panel B of the figures plot the individual components of the financial decisions of the firm as functions of the market leverage before financing: equity issuances/repurchases, debt issuances/reductions, cash balance increases/decreases, and dividend payouts.

First, I will describe the financial policies for the simplest model, i.e., the second benchmark model without transaction costs. As this model is a standard trade-off model, the firm has an optimal target leverage. This is reflected in the leverage policy function (in Panel A of Figure 2) as a flat line with the target leverage at about $65 \%$. However, when the firm's leverage before financing is higher than the target leverage, the optimal policy coincides with a portion of the

\footnotetext{
${ }^{23}$ The numbers 0.8 and 0.2 are arbitrarily chosen for concreteness, any pair of numbers from the intervals $(0.5,1]$ and $[0,0.5)$ will generate qualitatively similar figures.
} 
$y=x$ line, i.e., the firm stays with the same leverage after financing, rather than reduces it to the target leverage. The intuition for this phenomenon is that when the firm has a high leverage, it is very costly to retire debt at face value, because the market value of debt can be much less than the face value of debt due to the substantial default risk. ${ }^{24}$ In fact, when leverage before financing is sufficiently high, the leverage policy functions for all three models coincide (or almost coincide) with a portion of the $45^{\circ}$ line, for the same reason. ${ }^{25}$ Therefore, in the following I will focus on the portion of the leverage policy functions for the lower leverage ratios before financing, away from the $45^{\circ}$ line.

Second, the leverage policy function for the first benchmark model (with costs) is a curve above the $45^{\circ}$ line and below the flat line (the policy function for the second benchmark model). The intuition is that the firm increases leverage towards the target, but the costs of financing prevent it from reaching the target leverage. The financing decisions of the firm (as shown in Panel B) are qualitatively similar to those of the second benchmark model, and quantitatively less dramatic due to the financing costs.

Next we turn to the leverage policy function for the main model conditional on investors being optimistic $(q=0.8)$, also depicted in Panel A of Figure 2. It is a curve below the $45^{\circ}$ line. This means that the firm always decreases its leverage when investors are optimistic, dramatically deviating from the benchmark policies. From Panel B of Figure 2, we see that the manager issues equity, retires debt, and increases cash balances, essentially the opposite of what the benchmark model predicts. The intuition of these results is that since equity prices are more sensitive to market mispricing than debt prices, the manager issues equity when the stock is overpriced, and the funds raised from equity issuance are used to repurchase debt or increase cash balances, to balance the budget of the firm. ${ }^{26}$ The combined effects of these actions on leverage are leverage-decreasing.

When investors are pessimistic $(q=0.2)$, Panel A of Figure 3 shows that the leverage policy

\footnotetext{
${ }^{24}$ If retirement of debt is by market value, then the leverage policy function would be a flat line for all leverage ratios. The assumption of retirement by face value is more consistent with reality and is now used in most trade-off models, such as Leland $(1994,1998)$.

${ }^{25}$ The leverage policy functions may not coincide perfectly with the $45^{\circ}$ line because although the firm does not reduce debt, it may issue a bit of equity to meet the coupon payment. The expectation of such an equity issuance can change the leverage before financing to a value slightly different from the leverage after financing.

${ }^{26}$ Such equity-for-debt exchanges are only profitable when the benefits of equity overvaluation is sufficiently high and exceed those of tax exemption on debt, which is the case for the high investor sentiment of $q=0.8$ here.
} 
function is a curve above the benchmark policy curve. Thus the firm always increases its leverage, and does so more aggressively than a firm without market timing incentives. Panel B of Figure 3 shows that the firm's financing activities are qualitatively similar to the benchmark policies, but more pronounced in quantities. Intuitively, when investors are pessimistic about the firm, the manager deviates from the benchmark policy by repurchasing more equity to take advantage of the undervaluation of the firm, and to finance the repurchases, issuing additional debt or reducing cash holdings further.

It is worth noting that the deviation of the firm's leverage policy from the benchmark policy conditional on high investor sentiment is much larger than the deviation conditional on low investor sentiment. The cause of this asymmetry is the interaction between market timing and the nonlinearity of bankruptcy costs. The marginal cost of bankruptcy is higher at high leverage ratios and lower at low leverage ratios. Therefore, it is more costly to conduct leverage-increasing market timing activities than leverage-decreasing activities, even if these are motivated by symmetric misvaluation of the firm's value. This asymmetry in market timing behavior has two important implications: first, the effect of market timing on leverage ratios when the firm is in boom is more important than when it is in recession; second, the effect of market timing on leverage ratios of firms on average is decreasing. The asymmetry of market timing provides the intuition behind many of the empirical predictions discussed in Section 5.

The optimal dividend policies conditional on investor sentiment are plotted in Panel B of Figure 2 and Figure 3. The firm pays more dividends when investors are optimistic and less (none, in fact, in the case of $q=.2$ ) when investors are pessimistic. ${ }^{27}$ Intuitively, when investors are optimistic, the manager issues equity to time the market, and thus has excess funds to dispose of - he can pay extra dividends in this case. On the other hand, when investors are pessimistic, the manager repurchases equity and is in need of addition funding which he can obtain through cutting back on dividend payouts.

The above analysis of the optimal financing policies provides much intuition about how firms act in the main model. However, it cannot lead directly to empirical predictions for the following

\footnotetext{
${ }^{27}$ Because there are other important aspects about dividend policies not modeled here, such as dividend smoothing concerns and tax issues, I choose not to emphasize on these results on dividend policy. Rather, these results should be viewed as giving the intuition about the partial effects of market timing on the payout policy, other things equal. Such predictions can be tested if other factors about payout policies are suitably controlled.
} 
reasons. First, the most important variable in the analysis, the investors' belief $q$, is endogenously determined in the model and unobservable in the real world. Second, in the dynamic model, the firm's history determines the relationship between investor sentiment, leverage decisions, and the firm's characteristic variables. In other words, the stationary distribution of the state vector is determined only in the dynamic process, for example, some state may never be reached in equilibrium. Therefore, to examine the empirical implications of the model, I conduct a simulation based on the optimal financial policies and carry out empirical analysis on the simulated data. This is the subject of the next section.

To obtain further intuition about the dynamic evolution of firms before turning to the empirical analysis, it is perhaps best to look at the history of a particular firm as an example. Figure 4 displays the 50-year financial history of a typical firm. Panel A plots the history of earnings, investor sentiment, and market leverage of the firm, i.e., the state variables of the model, and Panel B plots the individual components of the financial decisions: net equity issuance, net debt issuance/cash balance changes, and dividend payout, as fractions of the total market value of firm. From Panel A, we note that the changes in the investors' sentiment are perfectly correlated with earnings shocks, a reflection of the updating formula (2). Also implied by (2), the levels of investor sentiment change more slowly and are thus more persistent than earnings. By examining whether the investor sentiment is higher or lower than the correct value $p_{0}=0.5,{ }^{28}$ the period can be roughly divided into two regions: the first 20 years and the latter years.

In the first region, investors have high sentiment $q>0.5$ and overvalue the firm. The market leverage is generally decreasing in this region due to the growing trend in earnings and investor sentiment. Panel B shows that in the first region, the firm issues equity, retires debt, or accumulate cash, and pay out dividends, consistent with the intuition from the numerical solution above. It is worth noting that the market overvaluation becomes so high in period 17 that the firm retires all of its debt and enter the territory of negative leverage. The firm keeps a positive cash balance until period 25 despite the fact that the earnings of the firm have been declining since period 17 . The intuition is that as investor sentiment changes more slowly than earnings, the firm does not find it profitable to restructure (which implies repurchasing equity and reducing cash balances) until when investor sentiment drops to about 0.5 in period 20. After period 20, the firm does begin to

\footnotetext{
${ }^{28} \mathrm{~A}$ subtle point is that due to the dynamic nature of the model, an investor sentiment of $q=0.5$ only means that investors are valuing the firm approximately correctly.
} 
repurchase or reduce cash holdings, but the variable costs prevents the firm from returning to a positive leverage ratio immediately.

In the second region, investors have low sentiment $q<0.5$ in general and undervalue the firm. Rather than paying dividends, the firm repurchases shares in this region. The firm also issues debt when leverage is very low (periods 24 and 25) and when investor's sentiment is especially low (period 30 and 40, for example.) However, when leverage is very high (period 44), even though the investor sentiment is low then, the firm keeps the same debt level. This reflects the portion of the $45^{\circ}$ line in the leverage policy function in Panel A of Figure 3 and is due to the high costs of retiring existing debt by face value, rather than market value.

\section{Empirical Implications of the Model from Simulation}

To investigate the empirical implications of the model, I obtain a panel data of firm's histories by simulating optimal financial policies of the manager, and conducting empirical analysis on the simulated data. I simulate the history of 1,000 firms for 70 periods (years). The initial earnings level is set to $N_{0}=1$ for each firm. The first 20 years of data are excluded from the final sample to focus on the steady state of firms' capital structure decisions. Firms may default during the period and the final sample consists of 49,238 firm-year observations for 1,000 unique firms over the period of 50 years. To distinguish the effects of market timing from effects of other factors, I also obtain similarly a simulated panel data for the benchmark model, in which the manager and investors have the correct belief and all other aspects are identical to the main model (i.e., the first benchmark model considered in the last Section.) The final sample for the benchmark model consists of 44,192 firm-year observations.

For comparison, I also consider an empirical panel data, which runs from 1973 to 2002 for 30 years. In 1973, 1,000 firms with the longest appearance in COMPUSTAT prior to 1973 are chosen. ${ }^{29}$ The final sample consists of all observations of these 1,000 firms, and amounts to 17,268 firm-year observations.

\footnotetext{
${ }^{29}$ This choice is made so that relatively mature firms are studied (the average age of firms in the sample is about 10 years), and the empirical capital structure decisions are thus more comparable to those of the steady-state solution in the models. Randomly choosing 1,000 firms in 1973, or choosing all firms in 1973 do not change the results qualitatively.
} 


\section{$5.1 \quad$ Summary Statistics}

The important variables of the empirical analysis are described below. Market leverage is defined to be the ratio of market debt to market assets, which is the sum of market debt and market equity. Book leverage is defined to be the ratio of market debt to book assets. Market-to-book ratio is the ratio of market assets to book assets. As investment is absent in the model, book assets is defined to be a constant. To be specific, book assets is chosen so that the median market-to-book ratio in the simulated data of the main model is equal to that in the empirical panel data. ${ }^{30}$ Profitability is defined as the ratio of earnings (before interest and taxes) to book assets.

Table 2 reports summary statistics of the simulated data of the main model and the benchmark model, and the empirical panel data. First, note that the statistics of the market-to-book ratio in both the main-model- and the benchmark-model-generated data match that in the empirical data quite well. Therefore, the model is successful in generating cross-sectional variations in marketto-book ratios similar to that in the empirical data. Second, the distribution of market and book leverage ratios in the main-model-generated data is similar to that in the empirical data, while leverage ratios in the benchmark-model-generated data are distributed within a higher and tighter range. These facts will be discussed in more detail in the later sections.

\subsection{Equity Issuance Decisions}

A large number of empirical studies have identified high stock returns as an important factor in managers' decision to issue equity; see, for example, Marsh (1982) for a sample of equity and debt issues in the UK from 1959 to 1974, Hovakimian, Opler, and Titman (2001) for a US Compustat sample from 1979 to 1997, and Hovakimian, Hovakimian, and Tehranian (2004) for a US Compustat sample from 1982 to 2000. In their survey of corporate executives, Graham and Harvey (2001) document that two-thirds of CFOs agree that "the amount by which our stock is undervalued or overvalued was an important or very important consideration" for equity issuance and nearly as many agree that "if our stock price has recently risen, the price at which we can sell is 'high'."

Table 3 reports the results of logit regressions of the equity issuance dummy variable on firms' characteristic variables in the simulated data set and compares them with the results of existing empirical studies. In Panel A, the sample consists of all firm-years that issue either equity or

\footnotetext{
${ }^{30}$ Since book assets is a constant, changing the value of this constant does not affect any of the results qualitatively.
} 
debt in that year, as in most empirical studies that compare the choice between debt and equity issuance. The first two columns of Panel A show that in the model, high one-year prior stock returns makes equity issuance more likely. Furthermore, another indicator of overvaluation, high market-to-book ratios, also increase the probability that the firm chooses equity over debt by the firm. The market leverage ratio is included as a control variable. This evidence is consistent with the results of Marsh (1982), Hovakimian, Opler, and Titman (2001), and Hovakimian, Hovakimian, and Tehranian (2004), at least qualitatively. ${ }^{31}$

Intuitively, the 1-year prior stock return and lagged market-to-book ratio reflect the most recent change in investor's belief and lagged investor's belief. Therefore, higher prior stock returns and higher market-to-book ratios signal higher investor's belief or sentiment and a greater probability that the stock is overpriced and the manager issues equity to exploit the overvaluation, as in Figure 2. There exists a related theoretical literature that explain this "hot equity issuance" phenomenon through different mechanisms. ${ }^{32}$ Most of these studies attempt to explain the facts within the rational expectations framework. My model deviates from the assumption of fully rational agents, but as a compensation, is able to explain capital structure choices of firms, and the long-run abnormal returns following corporate events, as discussed below.

Panel B of Table 3 pits equity-issuing firms against firms that do not issue either equity or debt. The results are similar to those in Panel A: higher stock returns or market-to-book ratios significantly increase the probability that a firm issues equity, consistent with the results of Hovakimian, Hovakimian, and Tehranian (2004).

\subsection{Long-run Performance of Financing Events}

It is well-documented that firms have negative long-run abnormal returns for up to 5 years after IPO (see, for example, Stigler (1964), Ritter (1991), and Brav and Gompers (1997)), and seasoned equity offers (see, for example, Loughran and Ritter (1995), Spiess and Affleck-Graves (1995), and

\footnotetext{
${ }^{31}$ The reason that the coefficients differ substantially in magnitude is that in my model earnings follows a simplified binary process and are not calibrated to the real earnings process. To match the empirical results quantitatively would require a more sophisticated model that models the distribution of earnings.

${ }^{32}$ See Lucas and McDonald (1990), Hennessy, Livdan, and Miranda (2007) for models based on asymmetric information. See Dittmar and Thakor (2007) for a model based on the degree of agreement between the manager and investors. See Pastor and Veronesi (2003), Carlson, Fisher, and Giammarino (2005), Li, Livdan, and Zhang (2006) for neoclassical models of corporate financing and investment.
} 
Pontiff and Woodgate (2006).), compared to non-issuing firms with similar characteristics. On the contrary, Ikenberry, Lakonishok, and Vermaelen (1995) show that firms that repurchase their stock experience positive long-run abnormal returns for up to four years after repurchases. These facts are hard to explain within the rational expectations framework as investors would adjust the market prices sooner if the long-run abnormal returns are expected.

Table 4 reports the long-run abnormal returns and the prior abnormal returns of various corporate financing events in the main-model-generated data. The abnormal return is defined as the difference between the return of the firm with that of a control firm matched by market-to-book ratio in the same year. As shown in Table 4, the model predicts that equity issuance, debt reduction, and increases in cash balances are accompanied by positive pre-event abnormal returns and negative post-event abnormal returns; equity repurchase, debt issuance, and decreases in cash balances, on the contrary, are preceded by negative pre-event abnormal returns and followed by positive post-event abnormal returns.

Intuitively, as shown in Figure 2 and 3, equity issuances and repurchases are the primary activities that create market timing benefits and therefore occur when the firm is overvalued and undervalued respectively. The financing actions that compensate the impact of equity issuance on the firm's balance sheet are debt reductions and cash accumulations and hence these are more likely to occur when the firm is overvalued, and hence accompanied with higher pre-event returns. Similarly, debt issuances and cash reductions are more likely to occur when the firm is undervalued, and accompanied by lower pre-event returns. The results on the long-run returns reflect the intuition that although investors may misvalue a firm temporarily, the market valuation on average reverts to correct levels in the long run.

Table 5 reports the year-by-year abnormal returns following equity issuance/repurchase of the main-model-generated data side by side with the empirical results of Loughran and Ritter (1991) and Ikenberry, Lakonishok, and Vermaelen (1995), respectively. Consistent with the empirical results, in the simulated data, firms that issue/repurchase equity have negative/positive abnormal returns in each of the 5 years (4 years for repurchases) following the event. This long-run effect reflects the fact that the investor sentiment is persistent (see formula (2)) and it reverts slowly to "normal" levels. 


\subsection{Low-Leverage and Zero-Leverage Phenomena}

There exist a number of stylized facts about the cross-sectional distribution of leverage ratios that seem puzzling within the trade-off framework. First, structural trade-off models usually produce higher leverage ratios than those of the empirical data. A benchmark financing model in Leland (1994) produces optimal leverage ratios as high as 70\% to $90 \%$, compared to the empirical average market leverage ratio of $26 \%$ for US firms in COMPUSTAT over the period 1987-2003, for example. A number of studies have been trying to identify theoretically the reasons why firms are on average low levered. ${ }^{33}$ This model identifies market timing as an independent factor that can lead to lower leverage ratios.

Second, a substantial fraction of firms exhibit extreme debt conservatism. Graham (2000) discovers that "paradoxically, large, liquid, profitable firms with low expected distress costs use debt conservatively" and leave significant amounts of potential tax benefits unused. Strebulaev and Yang (2007) find that about 10\% of large US public firms have zero debt outstanding over the period 1963-2002. The fraction of firms with negative net debt outstanding (debt minus cash balances) is about $30 \%$ over the same period. Moreover, zero-leverage firms are also more profitable, pay more dividends and taxes, keep larger cash balances than other firms. Considering the fact that cash has a tax disadvantage, zero-debt firms have particularly large unrealized tax benefits.

Figure 5 shows the distribution of market leverage ratios in the empirical data, the benchmark case, and the main model, in Panel A, B, and C, respectively. Panel B shows that the benchmark model generates a leverage distribution very different from that the empirical distribution in Panel A. In the benchmark model, market leverage ratios are bounded within the interval [50\%, 90\%] with a mean leverage ratio at $65 \%,{ }^{34}$ while the empirical market leverage spans a much wider range from $-80 \%$ to $100 \%$, with a mean leverage of $21 \%$ and a fraction $17 \%$ of firms with negative net leverage. The failure of the benchmark model reflects the low-leverage and zero-leverage phenomena described above. Intuitively, transaction costs can only cause a limited deviation from the target leverage in a trade-off model, and cannot lower the mean leverage ratio by much.

\footnotetext{
${ }^{33}$ See for example, Goldstein, Ju, and Leland (2001), Ju, Parrino, Poteshman, and Weisbach (2005), Morellec (2003), and Strebulaev (2007).

${ }^{34}$ The distribution is asymmetric within the interval [50\%,90\%] because firms do not retire debt at very high leverage, due to the high costs of retirement by face value, as shown by the higher portion of the benchmark policy function in Figure 2 .
} 
Panel $\mathrm{C}$ shows that the main model generates a distribution widely distributed between $-65 \%$ and $100 \%$, with a mean leverage of $33 \%$ and a fraction of $11 \%$ of firms with negative leverage, very similar to the empirical distribution. The low average leverage is driven by the asymmetry of effects of market timing for the cases of high and low investor sentiment, shown in Figure 2 and 3. The fact that bankruptcy costs are non-linear with a higher curvature at higher leverage ratios implies that it is more costly to increase leverage than to decrease leverage. Therefore, despite the fact that investors may overvalue or undervalue a firm with the same probabilities, firms respond more to overpricing than to underpricing and have on average lower leverage ratios than in the benchmark case. The intuition of the substantial presence of firms with zero debt is that the manager issues equity and reduces debt holdings when the firm is sufficiently overvalued (as shown in Figure 2) and sustained period of high investor sentiment (which is likely to happen as investor sentiment is persistent) can lead to repeated reductions and zero-debt policy (as in the case of Figure 4).

Strebulaev and Yang (2007) study "jump-down" and "jump-up" firms, i.e., firms with large changes in their leverage ratios either when the firm decreases leverage and starts following zeroleverage policy or when it stops it and increases leverage, and document that jump-down (jump-up) firms experience abnormally high (low) stock returns and large increases (decreases) in cash flows in the year prior to the adjustment. This evidence is consistent with the model's explanation of the zero-leverage behavior.

Table 6 reports the comparison of profitability, dividend payout, and cash holdings between zero-leverage dividend-payers and average dividend payers, in the model-generated data and the empirical data. Panel B shows that the model predicts that zero-debt firms are much more profitable, pay much higher dividends, and keep a much larger cash balance than average firms, consistent with the empirical evidence in Panel A and Strebulaev and Yang (2007). Intuitively, zero-leverage firms are more profitable because profitability proxys for investor's belief, which is high for these firms. Because overvalued firms pay more dividends (Panel B of Figure 2), zero-leverage firms pay higher dividends than average firms. As the result of being more profitable and issuing more equity with no debt obligations to meet, the zero-leverage firms have a larger cash inflow each period, and thus keep a larger cash balance. 


\subsection{Correlation of Leverage with Profitability}

The negative correlation between profitability and both the book and the market leverage ratios is a very robust empirical fact documented in many empirical studies of capital structure. ${ }^{35}$ This stylized fact was previously viewed as a major setback to the trade-off theory, as more profitable firms pay higher taxes and should benefit more by increasing leverage. Strebulaev (2007) explains the negative relationship between profitability and the market leverage through the infrequent adjustment of capital structure within a dynamic trade-off framework. Intuitively, due to transaction costs, firms can become more profitable and thus lower-levered, but do not adjust capital structure immediately. Such inactive periods can lead to a negative relationship between leverage and profitability in cross-section.

Table 7 reports the results of linear regressions of leverage ratios with profitability as the independent variable, conducted for the empirical data, and the simulated data of the benchmark model and the main model. Panel A shows the results with book leverage as the dependent variable and Panel B with market leverage. Column 1 of Panel A confirms the previously documented negative correlation between profitability and book leverage. In Column 2 of Panel A, the benchmark model predicts a positive correlation between profitability and book leverage, inconsistent with empirical evidence. The intuition is that a trade-off model with transaction costs can only lead to infrequent adjustment, but cannot lead to adjustment in the opposite direction predicted by the trade-off theory. Column 3 of Panel A shows that the main model predicts the negative correlation, consistent with empirical evidence. The intuition is that profitability is a proxy for investor sentiment and, as shown in Figure 2, and more profitable firms are more likely to issue equity and reduce debt, i.e., conduct an active policy in the opposite direction predicted by the trade-off theory.

Column 2 of Panel B shows that the negative correlation between profitability and market leverage is correctly predicted in the benchmark model, due to the mechanism noted in Strebulaev (2007). Column 3 of Panel B confirms that the main model also generates the consistent prediction. Comparing in Panel A and B, the coefficient of the regressions decrease when the dependent variable changes from book leverage to market leverage. This is also due to the effect of infrequent adjustment noted in Strebulaev (2007).

\footnotetext{
${ }^{35}$ See, for example, Rajan and Zingales (1995) and Fama and French (2002).
} 


\section{Discussions}

A natural extension of the model is to include endogenous investment so that we can learn how investment decisions interact with financial decisions with market timing. Such a model would also allow more realistic treatment of book assets and market-to-book ratios. Untabulated results from a simple preliminary model suggest that the manager issues equity and overinvests when investors are optimistic. The intuition is that the manager increases investment and the amount of "cheap" capital raised to maximize the resulting market timing benefits. Similarly, the manager chooses to issue debt and underinvests when investors are pessimistic. This is consistent with Dittmar and Thakor (2007), who find that firms invest more after equity financing than debt financing.

While I model investors' sentiment as coming from extrapolation of firms' earnings history, in reality there can be many sources of investors' sentiment. For example, trends in the firm's stock returns may generate some sentiment, on top of the effects of earnings, and the performance of the aggregate stock market, or an industry sector can also generate investors' sentiment. The aggregate market sentiment is particularly important in predicting equity issuances, as equity issuances are often clustered in so-called "hot periods" (e.g., Marsh (1982) and Bayless and Chaplinsky (1996)). Baker and Wurgler (2006) proposes a number of proxies of aggregate investor sentiment and find that they do predict future returns. It would be interesting to see the implications of models of, for example, an aggregate investor sentiment.

While the model can generate a number of well-documented stylized facts, it would be interesting if the model can be tested with additional predictions, in particular, cross-sectional predictions. One such possibility is to find proxies for the investors' extrapolation bias or the difference of opinions between investors and the manager. Greater biases or differences would imply greater market timing incentives of the manager and hence greater impact on capital structure of the firm, in particular, a lower debt ratio, and a greater probability of having zero debt. One potential such proxy is the idiosyncratic risk. Firms with higher idiosyncratic risk are presumably less transparent to investors and thus more subject to extrapolation. Another proxy is the fraction of institutional holdings of the firm's stock, as institutional investors are likely to be less subject to the extrapolation bias than individual investors. 


\section{Conclusion}

In this paper, I propose a dynamic model of financing that explains a number of stylized facts about corporate financing and the cross-sectional capital structure. The model offers a parsimonious treatment of endogenous external financing, payout, and cash policies. In the model, investors overextrapolate from trends of earnings growth while the manager is rational. The model explains the high stock returns predicting equity issuance, the negative/positive long-run abnormal returns following stock issuances/repurchases, the low leverage in cross-section, the substantial presence of firms with no debt or negative net debt, and a negative relationship between profitability and both book and market leverage ratios. This model should be viewed as a first step towards understanding the market timing phenomenon and its deeper implications. Possible extensions of the model include adding endogenous investment and considering aggregate investor sentiment.

\section{Appendix A Procedure of Numerical Solution}

The numerical solution of the model is obtained through a dynamic programming iteration. As the state variables are continuous, discretization is used. In particular, 11 points, geometrically distributed between $[.01,100]$, are used for $N_{t}, 11$ grid points, equally spaced between $[0,1]$, are used for $q_{t}$, and 21 points are used for $c_{t} .{ }^{36}$ The value functions are represented as functions on the grid points, and piecewise linear interpolation is used when function values on non-grid points are needed.

In the numerical solution of the model, we first compute investors' anticipated optimal financing policies and value functions through recursive dynamic programming. Then we compute the manager's actual optimal financing policies and value functions, which depend on the investors' value functions, as can be seen from (5). Stationary solutions are found by iterating the recursive procedure until value and policy functions between adjacent iterations are less than $10^{-4}$. Normally, the procedure converges within 300 iterations.

\section{References}

Agrawal, Anup, and Nandu J. Nagarajan, 1990, Corporate Capital Structure, Agency Costs, and Ownership Control: The Case of All-Equity Firms, Journal of Finance, 45, 1325-1331.

Altinkilic, Oya, and Robert S. Hansen, 2000, Are There Economies of Scale in Underwriting Fees? Evidence of Rising External Financing Costs, Review of Financial Studies 13, 191-218.

Andrade, Gregor, and Steven N. Kaplan, 1998, How costly is financial (not economic) distress? Evidence from highly leveraged transactions that became distressed, Journal of Finance 53, 1443-1493.

\footnotetext{
${ }^{36}$ Use of finer grids does not change any of the results qualitatively.
} 
Alti, Aydogan, 2006, How Persistent Is the Impact of Market Timing on Capital Structure?, Journal of Finance 61, $1681-1710$.

Baker, Malcolm and Jeffrey Wurgler, 2000, The Equity Share In New Issues and Aggregate Stock Returns, Journal of Finance 55, 2219-2257.

Baker, Malcolm and Jeffrey Wurgler, 2002, Market Timing and Capital Structure, Journal of Finance 57, $1-32$.

Baker, Malcolm and Jeffrey Wurgler, 2006, Investor Sentiment and the Cross-Section of Stock Returns, Journal of Finance 61, 1645-1680.

Barberis, Nicholas, Ming Huang, and Tano Santos, 2001, Prospect Theory and Asset Prices, Quarterly Journal of Economics 116, 1-53.

Barberis, Nicholas, Andrei Shleifer, and Robert Vishny, 1998, A Model of Investor Sentiment, Journal of Financial Economics 49, 307-343.

Bayless, Mark, and Susan Chaplinsky, 1996, Is there a window of opportunity for seasoned equity issuance?, Journal of Finance 51, 253-278.

Bloomfield, Robert, and Jeffrey Hales, 2002, Predicting the next step of a random walk: experimental evidence of regime-shifting beliefs, Journal of Financial Economics 65, 397-414.

Bolger F., Harvey N., 1993, Context-sensitive heuristics in statistical reasoning, Quarterly Journal of Experimental Psychology 46A, 779-811.

Brav, Alon, and Paul A. Gompers, 1997, Myth or Reality? The Long-Run Underperformance of Initial Public Offerings: Evidence from Venture and Nonventure Capital-Backed Companies, Journal of Finance $52,1791-1821$.

Carlson, Murray, Adlai Fisher, and Ron Giammarino, 2006, Corporate investment and asset price dynamics: Implications for SEO event studies and long-run performance, Journal of Finance 61, 1009-1034.

Daniel, Kent D., David Hirshleifer, and Avanidhar Subrahmanyam, 1998, Investor psychology and security market under- and over-reactions, Journal of Finance 53, 1839-1885.

De Bondt, W., 1993, Betting on trends: intuitive forecasts of Financial risk and return, International Journal of Forecasting 9, 355-371.

Denis, David J., and Atulya Sarin, 2001, Is the Market Surprised by Poor Earnings Realizations Following Seasoned Equity Offerings?, Journal of Financial and Quantitative Analysis 36, 169-193.

Fama, Eugene F., 1998, Market Efficiency, Long-Term Returns, and Behavioral Finance, Journal of Financial Economics 49, 283-306.

Fama, Eugene F., and Kenneth R. French, 2002, Testing Trade-Off and Pecking Order Predictions about Dividends and Debt, Review of Financial Studies 15, 1-33.

Fischer, Edwin O., Robert Heinkel, and Josef Zechner, 1989, Optimal Dynamic Capital Structure Choice: Theory and Tests, Journal of Finance 44, 19-40.

Flannery, Mark J., and Kasturi P. Rangan, 2006, Partial adjustment toward target capital structures, Journal of Financial Economics 79, 465-506.

Frank, Murray, and Vidhan K. Goyal, 2003, Testing the Pecking Order Theory of Capital Structure, Journal of Financial Economics 67, 217-248.

Gilovich, Thomas, Robert Vallone, and Amos Tversky, 1985, The Hot Hand in Basketball: On the Misperception of Random Sequences, Cognitive Psychology 17, 295-314.

Goldstein, Robert, Nengjiu Ju, and Hayne E. Leland, 2001, An EBIT-Based Model of Dynamic Capital Structure, Journal of Business 74, 483-512.

Gomes, Joao F., 2001, Financing investment, American Economic Review 91, 1263-1288. 
Graham, John R., 2000, How Big Are the Tax Benefits of Debt, Journal of Finance 55, 1901-1941.

Graham, John R., and Campbell R. Harvey, 2001, The Theory and Practice of Corporate Finance: Evidence from the Field, Journal of Financial Economics 60, 187-243.

Hennessy, Chris, and Toni Whited, 2005, Debt Dynamics, Journal of Finance, 60, 1129-1165.

Hennessy, Christopher A., Dmitry Livdan, and Bruno Miranda, 2007, Corporate financing under repeated adverse selection, Working Paper, UC Berkeley and UCLA.

Hong, Harrison, and Jeremy C. Stein, 1999, A unified theory of underreaction, momentum trading and overreaction in asset markets, Journal of Finance 54, 2143-2184.

Hong, Harrison, Jeremy C. Stein, and Jialin Yu, 2006, Simple forecasts and paradigm shifts, Journal of Finance, forthcoming.

Hovakimian, Armen, Tim Opler, and Sheridan Titman, 2001, The debt-equity choice, Journal of Financial and Quantitative Analysis 36, 1-24.

Hovakimian, Armen, Gayane Hovakimian, and Hassan Tehranian, 2004, Determinants of target capital structure: The case of dual debt and equity issues, Journal of Financial Economics 71, 517-540.

Ikenberry, David, Josef Lakonishok, and Theo Vermaelen, 1995, Market Underreaction To Open Market Share Repurchases, Journal of Financial Economics 39, 181-208.

Jenter, Dirk, 2004, Market Timing and Managerial Portfolio Decisions, Journal of Finance, forthcoming.

Jenter, Dirk, Katharina Lewellen, and Jerold B. Warner, 2007, Security Issue Timing: What Do Managers Know, and When Do They Know it?, working paper, MIT, Dartmouth College and University of Rochester.

Johnson, Joseph, and Gerard J. Tellis, 2005, Blowing Bubbles: Heuristics and Biases in the Run-Up of Stock Prices, Journal of the Academy of Marketing Science 33, 486-503.

Ju, Nengjiu, Robert Parrino, Allen M. Poteshman, and Michael S. Weisbach, 2005, Horse and Rabbits? Optimal Dynamic Capital Structure from Shareholder and Manager Perspectives, Journal of Financial and Quantitative Analysis, 259-281.

Kayhan, Ayla, and Sheridan Titman, 2006, Firms' Histories and Their Capital Structure, Journal of Financial Economics, forthcoming.

Lakonishok, Josef, Andrei Shleifer, and Robert W. Vishny, 1994, Contrarian investment, extrapolation, and risk, Journal of Finance 49, 1541-1578.

La Porta, Rafael, 1996, Expectations and the Cross-Section of Stock Returns, Journal of Finance 51, $1715-1742$.

Leary, Mark T., and Michael R. Roberts, 2005, Do Firms Rebalance their Capital Structures? Journal of Finance 60, 2575-2619.

Leland, Hayne E., 1994, Corporate Debt Value, Bond Covenants, and Optimal Capital Structure, Journal of Finance 49, 1213-1252.

Leland, Hayne E., 1998, Agency Costs, Risk Management, and Capital Structure, Journal of Finance 53, $1213-1243$.

Leland, Hayne E., and Klaus Toft, 1996, Optimal Capital Structure, Endogenous Bankruptcy, and the Term Structure of Credit Spreads, Journal of Finance 51, 987-1019.

Lemmon, Michael L., Michael R. Roberts, and Jaime F. Zender, 2006, Back to the Beginning: Persistence and the Cross-Section of Corporate Capital Structure, Working paper, University of Utah.

Li, Erica X.N., Dmitry Livdan, and Lu Zhang, 2006, Optimal Market Timing, working paper, University of Rochester, and Texas A\&M University. 
Loughran, Tim, and Jay Ritter, 1997, The Operating Performance of Firms Conducting Seasoned Equity Offerings, Journal of Finance 52, 1823-1850.

Lucas, Deborah J. and Robert L. McDonald, 1990, Equity Issues and Stock Price Dynamics, Journal of Finance 45, 1019-1043.

Marsh, Paul, 1982, The choice between equity and debt: an empirical study, Journal of Finance 37, 121-144.

Mikkelson, Wayne H., and M. Megan Partch, 1986, Valuation effects of security offerings and the issuance process, Journal of Financial Economics 15, 31-60.

Morellec, Erwan, 2003, Can Managerial Discretion Explain Observed Leverage Ratios?, Review of Financial Studies, 17, 257-294.

Muradoglu, Gulnur, 2002, Portfolio Managers' and Novices' Forecasts of Risk and Return: Are There Predictable Forecast Errors? Journal of Forcasting 21, 395-416.

Myers, Stuart C., and Nicholas Majluf, 1984, Corporate Financing and Investment Decisions when Firms have Information that Investors Do Not Have, Journal of Financial Economics 13, 187-221.

Pastor, Lubos, and Pietro Veronesi, 2003, Stock valuation and learning about profitability, Journal of Finance $58,1749-1789$.

Pontiff, Jeffrey and Artemiza Woodgate, 2006, Share Issuance and Cross-Sectional Returns, Journal of Finance, forthcoming.

Rajan, Raghuram G., and Luigi Zingales, 1995, What Do We Know about Capital Structure? Some Evidence from International Data, Journal of Finance 50, 1421-1460.

Rajan, Raghuram G., and Henri Servaes, 1997, Analyst Following of Initial Public Offerings, Journal of Finance 52, 507-529.

Ritter, Jay, 1991, The Long-Run Performance of Initial Public Offerings, Journal of Finance 42, 365-394.

Shleifer, Andrei, and Robert W. Vishny, 2003, Stock market driven acquisitions, Journal of Financial Economics 70, 295-311.

Spiess, Katherine, and John Affleck-Graves, 1995, Underperformance In Long-Run Stock Returns Following Seasoned Equity Offerings, Journal of Financial Economics 38, 243-267.

Stigler, George J., 1964, Public Regulation of the Securities Markets, Journal of Business 37, 117-142.

Strebulaev, Ilya A., 2007, Do Tests of Capital Structure Theory Mean What They Say?, Journal of Finance, forthcoming.

Strebulaev, Ilya A., and Baozhong Yang, 2007, The Mystery of Zero-Leverage Firms, working paper, Stanford University.

Schultz, Paul, 2003, Pseudo Market Timing and the Long-Run Underperformance of IPOs, Journal of Finance 58, 483-517.

Teoh, Siew Hong, Ivo Welch, and T. J. Wong, 1998a, Earnings Management and the Long-Run Market Performance of Initial Public Offerings, Journal of Finance 53, 1935-74.

Teoh, Siew Hong, Ivo Welch, and T. J. Wong, 1998b, Earnings Management and the Underperformance of Seasoned Equity Offerings, Journal of Financial Economics 50, 63-99.

Titman, Sheridan, and Sergey Tsyplakov, 2007, A Dynamic Model of Optimal Capital Structure, Review of Finance 2007, 401-451.

Tversky, Amos, and Daniel Kahneman, 1974, Judgment under uncertainty: heuristics and biases, Science $185,1124-131$. 


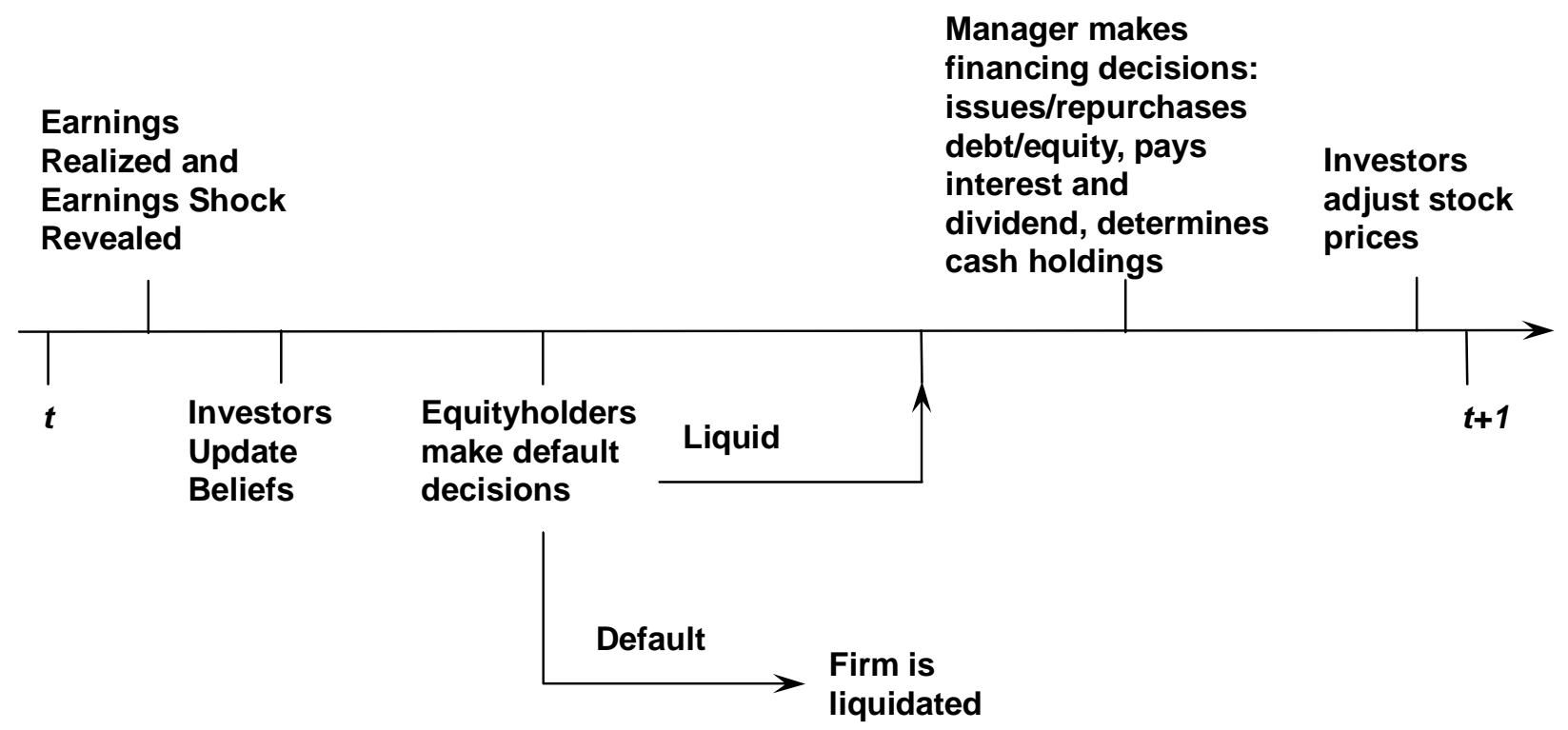

Figure 1: Timeline of the Model 
Panel A: Market Leverage Before Financing and After Financing

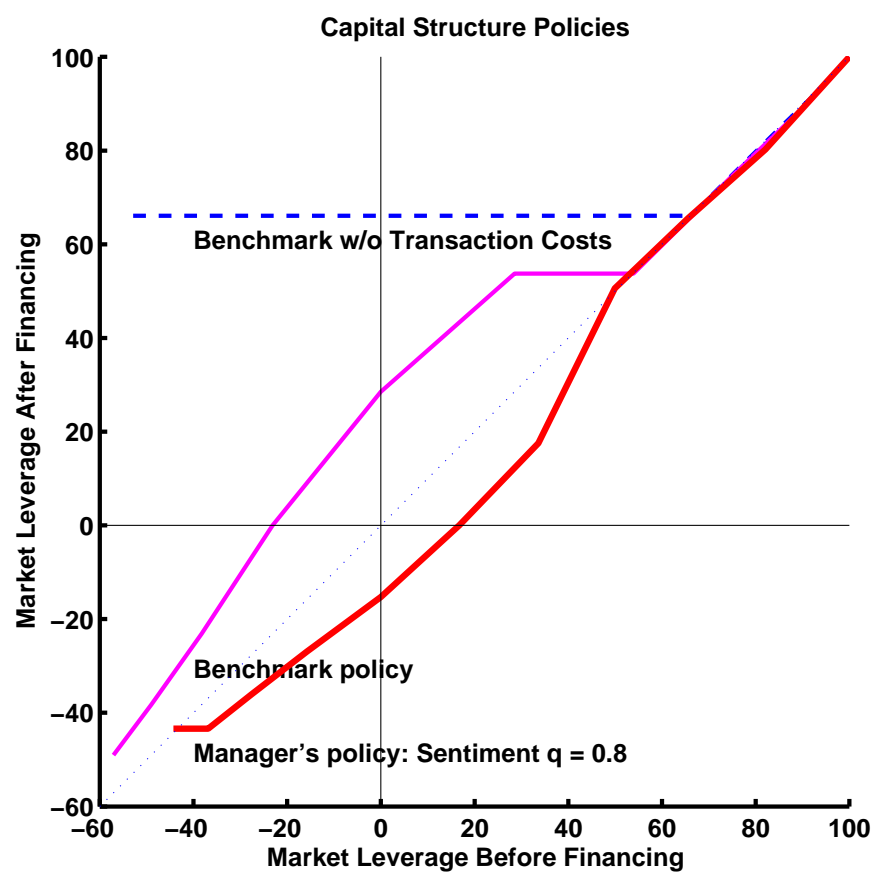

Panel B: Components of Financing Policies
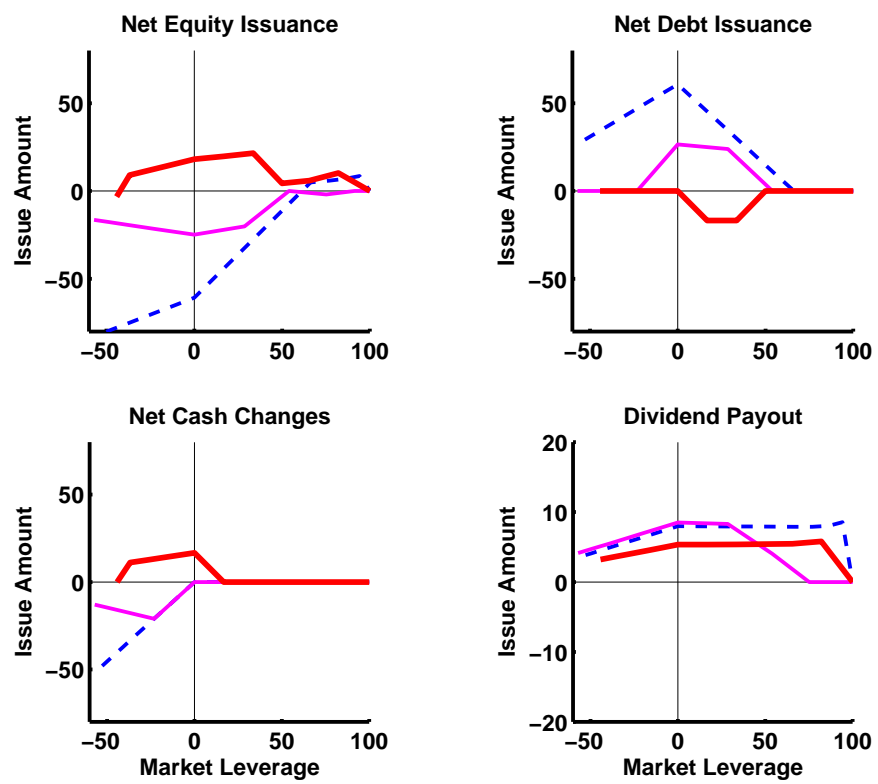

Figure 2: Financial Policies of the Main Model and Benchmark Models When Investor Sentiment is High: $q=0.8$

In both Panel A and B, the dashed line is the leverage policy function of the benchmark model without transaction costs, and the thinner solid line of the benchmark model with transaction costs, the thicker solid line of the main model. In Panel A, the dotted line is the $y=x$ line. In Panel B, the vertical axis is the issuance/payout amount as percentage of the total firm value before the financial decision. 
Panel A: Market Leverage Before Financing and After Financing

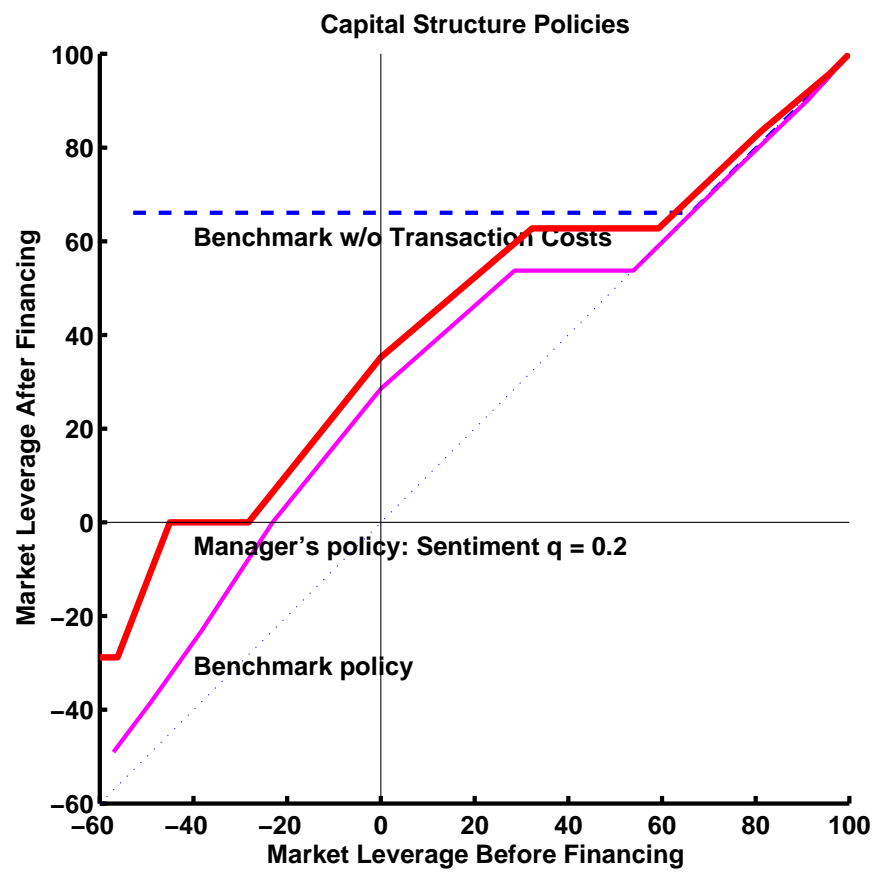

Panel B: Components of Financing Policies
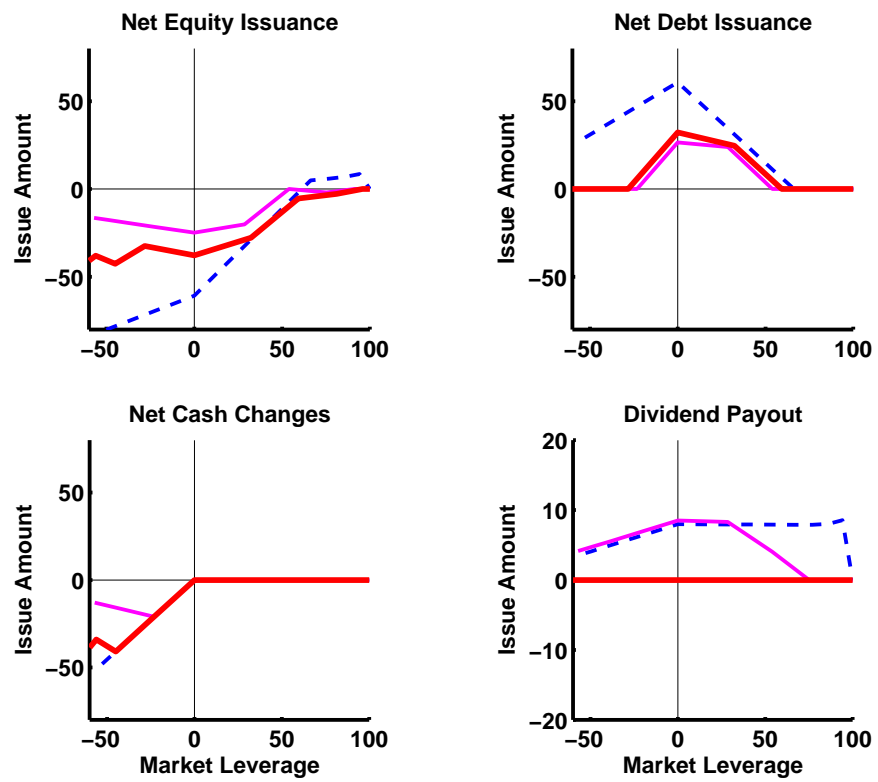

Figure 3: Financial Policies of the Main Model and Benchmark Models When Investor Sentiment is Low: $q=0.2$

In both Panel A and B, the dashed line is the leverage policy function of the benchmark model without transaction costs, and the thinner solid line of the benchmark model with transaction costs, the thicker solid line of the main model. In Panel A, the dotted line is the $y=x$ line. In Panel B, the vertical axis is the issuance/payout amount as percentage of the total firm value before the financial decision. 
Panel A. History of Earnings, Investor Sentiment, and Market Leverage

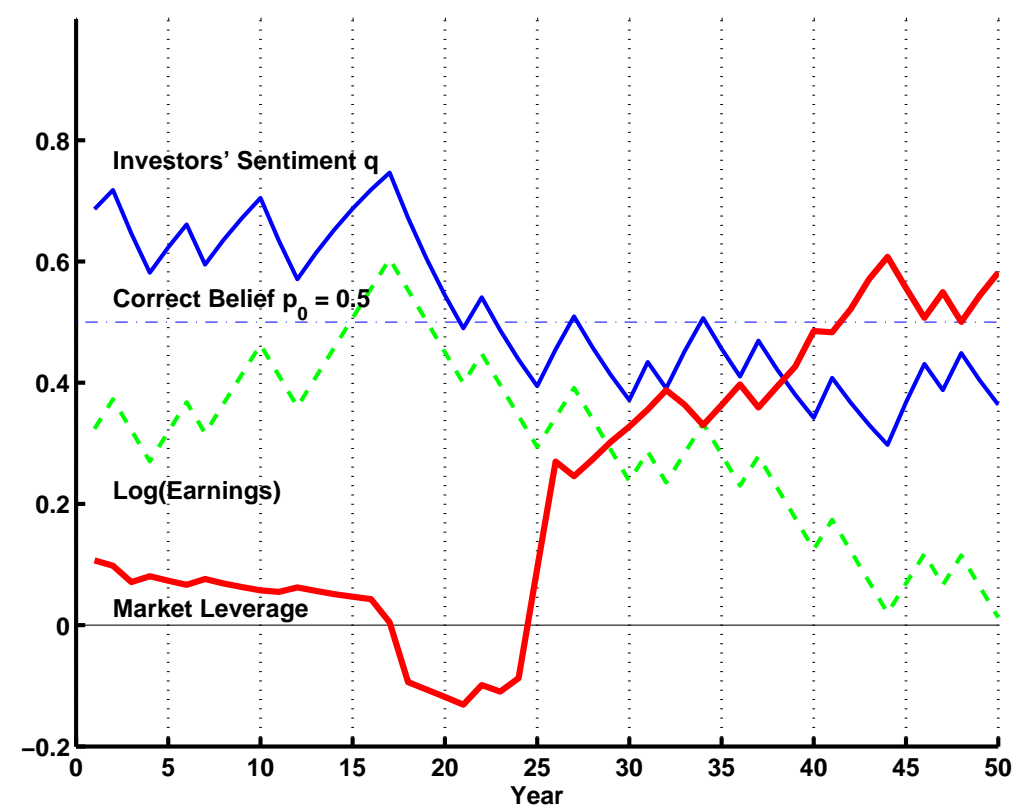

Panel B. History of Individual Financial Decisions
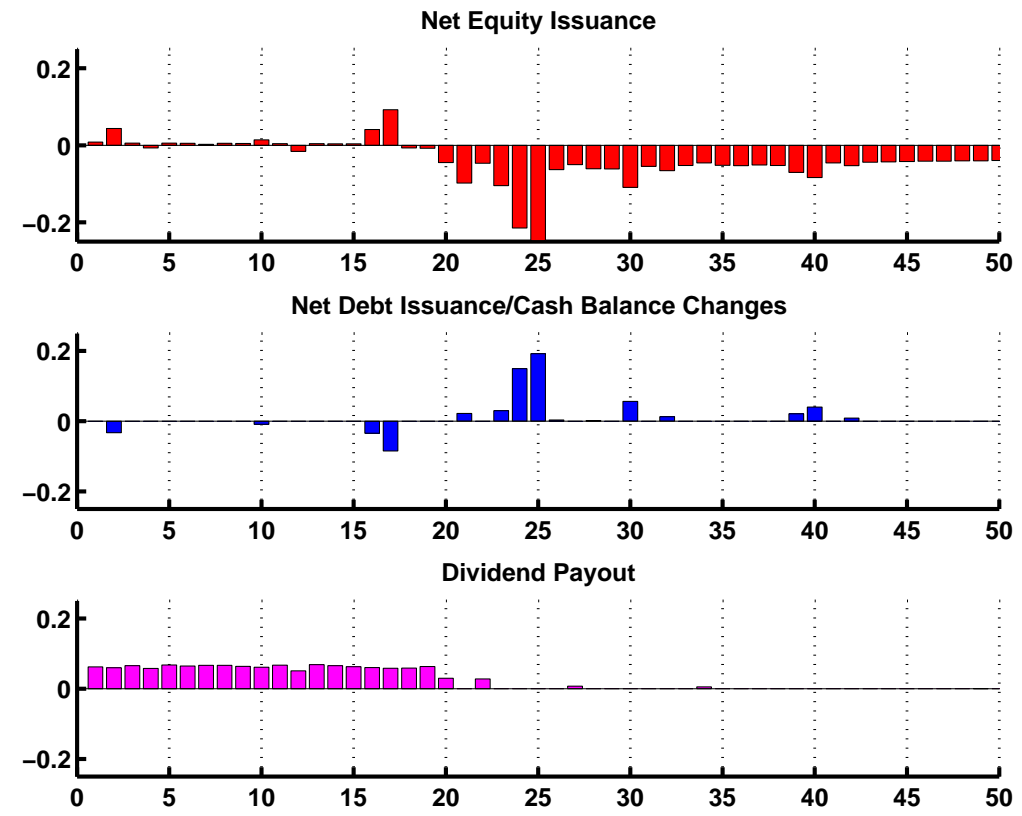

Figure 4: The History of a Typical Firm

In Panel A, the dashed line is the path of log earnings, the thinner solid line is the path of investors' belief, the thicker line is the path of market leverage ratios, and the thin dash-dot line represents the correct belief (or the manager's belief) $p_{0}=0.5$. In Panel $\mathrm{B}$, the vertical axis is the issuance/payout amount as percentage of the total firm value before the financial decision. 

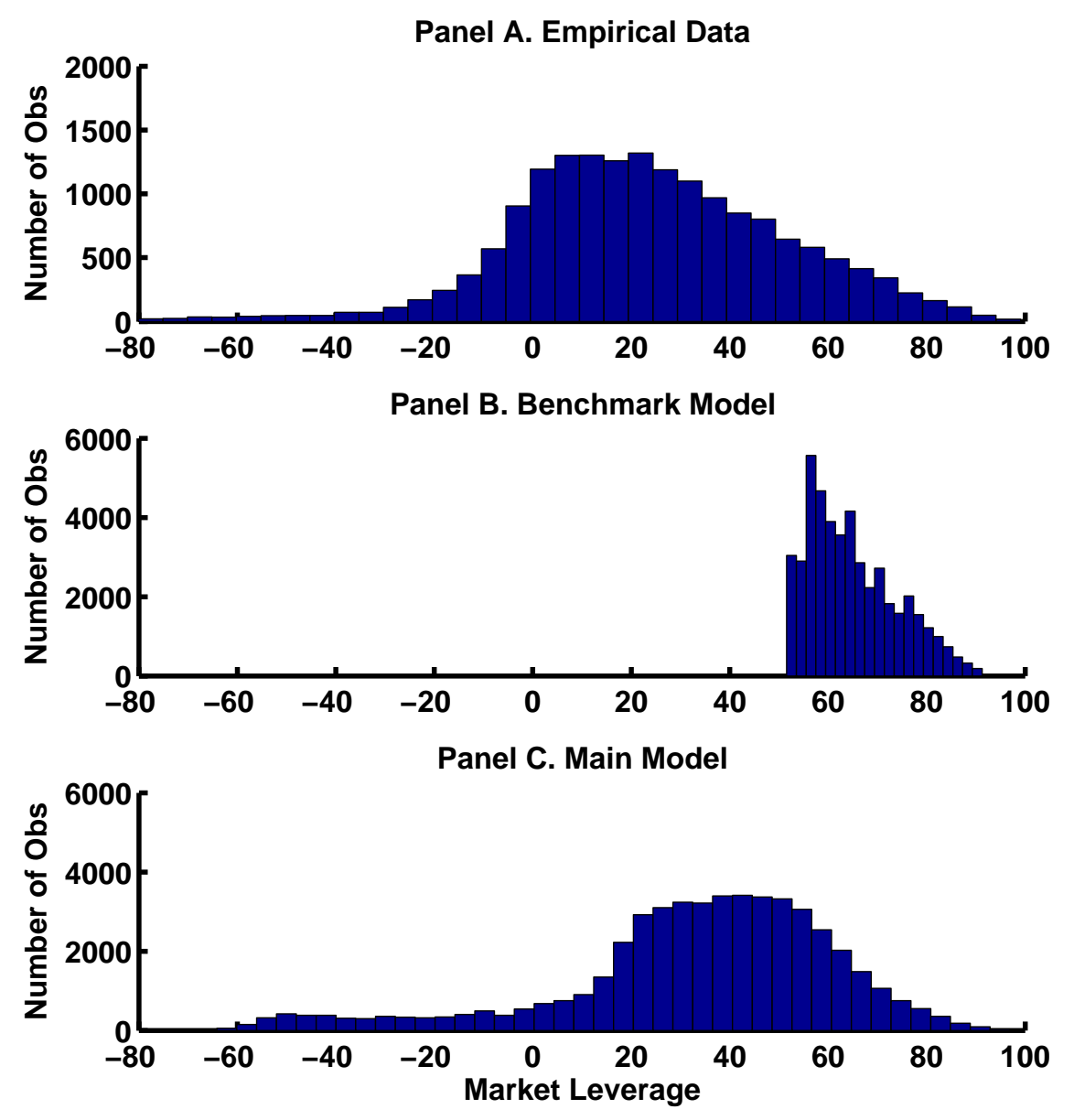

Figure 5: Distribution of Market Leverage Ratios

Panel A plots the distribution of market leverage ratios in the empirical panel data. The empirical data runs from 1973 to 2002 for 30 years. In 1973, 1,000 firms with the longest appearance in COMPUSTAT are chosen. The final sample consists of all observations of these 1,000 firms between 1973 and 2002. In the empirical data, net book debt is book debt minus cash holdings; market leverage is the ratio of the net book debt to market assets. Panel B and $\mathrm{C}$ plot the distribution of market leverage ratios in the simulated panel data for the benchmark model and the main model. The benchmark model is the model in which both the manager and investors have the correct belief. The main model is the model in which investors overextrapolate and the manager is rational. The simulation generates a random sample of 1,000 firms for 70 years, following the optimal financing strategies of the models. The first 20 years are excluded from the final panel data. In the simulated data, market leverage is the ratio of market debt to market assets. 
Table 1: Parameters of the Model

The base parameters of the model are given below.

\begin{tabular}{lll}
\hline Parameters & Description & Values \\
\hline$y$ & size of shock to earnings growth & 0.05 \\
$r$ & expected return for the firm & 0.1 \\
\hline$\tau$ & corporate tax rate & 0.2 \\
$\lambda$ & bankruptcy recovery rate & 0.8 \\
\hline$p_{0}$ & probability of a good shock & 0.5 \\
$\rho$ & investor's weight for new informa- & 0.1 \\
& tion & \\
\hline$c_{1}^{E}$ & linear transaction costs for equity & 0.05 \\
$c_{2}^{E}$ & liquidity costs for equity & 0.2 \\
\hline
\end{tabular}


Table 2: Summary Statistics from Simulation and Empirical Data

Panel A reports summary statistics of an empirical panel data. The empirical data runs from 1973 to 2002 for 30 years. In 1973, 1,000 firms with the longest appearance in COMPUSTAT are chosen. The final sample consists of all observations of these 1,000 firms between 1973 and 2002. In the empirical data, net book debt is book debt minus cash holdings; market leverage is the ratio of the net book debt to market assets; book leverage is the ratio of net book debt to book assets; MA/BA is the ratio of market assets to book assets; profitability is the ratio of EBIT to book assets. Panel B and C report summary statistics of simulated panel data for the benchmark model and the main model. The benchmark model is the model in which both the manager and investors have the correct belief. The main model is the model in which investors overextrapolate and the manager is rational. The simulation generates a random sample of 1,000 firms for 70 years, following the optimal financing strategies of the models. The first 20 years are excluded from the final panel data. In the simulated data, market leverage is the ratio of market debt to market assets; book assets is a constant $(=9.52)$ so that the median MA/BA is equal to the median ratio from the empirical data; book leverage is the ratio of market debt to book assets.

Panel A. Empirical Data (Number of Observations $=17,268$ )

\begin{tabular}{lccccccc}
\hline & Mean & 10pct & 25pct & Median & 75pct & 90pct & Std \\
\hline Market Leverage & 0.23 & -0.08 & 0.05 & 0.22 & 0.42 & 0.60 & 0.29 \\
Book Leverage & 0.17 & -0.08 & 0.05 & 0.18 & 0.29 & 0.40 & 0.22 \\
MA/BA & 1.26 & 0.74 & 0.87 & 1.05 & 1.39 & 1.96 & 0.76 \\
Profitability & 0.14 & 0.05 & 0.10 & 0.14 & 0.19 & 0.24 & 0.09 \\
\hline
\end{tabular}

Panel B. Benchmark Model (Number of Observations = 44,192)

\begin{tabular}{lccccccc}
\hline & Mean & 10pct & 25pct & Median & 75 pct & 90pct & Std \\
\hline Market Leverage & 0.65 & 0.54 & 0.58 & 0.63 & 0.71 & 0.78 & 0.09 \\
Book Leverage & 0.68 & 0.52 & 0.57 & 0.65 & 0.76 & 0.89 & 0.16 \\
MA/BA & 1.06 & 0.69 & 0.83 & 1.01 & 1.24 & 1.49 & 0.34 \\
Profitability & 0.11 & 0.07 & 0.08 & 0.10 & 0.13 & 0.15 & 0.03 \\
\hline
\end{tabular}

Panel C. Main Model (Number of Observations = 49,238)

\begin{tabular}{lccccccc}
\hline & Mean & 10pct & 25pct & Median & 75 pct & 90 pct & Std \\
\hline Market Leverage & 0.33 & -0.04 & 0.22 & 0.38 & 0.52 & 0.64 & 0.28 \\
Book Leverage & 0.26 & -0.06 & 0.28 & 0.38 & 0.42 & 0.45 & 0.34 \\
MA/BA & 1.23 & 0.62 & 0.80 & 1.05 & 1.40 & 1.92 & 0.75 \\
Profitability & 0.10 & 0.06 & 0.08 & 0.10 & 0.12 & 0.15 & 0.04 \\
\hline
\end{tabular}


Table 3: Equity Issuance Decisions

This table reports the results of multinomial logit regressions for the simulated panel data from the model, together with empirical results from previous studies. The dependent variable is the dummy for equity issuance. In Panel A, the sample consists of all firms that issue positive amount of debt or equity; in Panel B, the sample consists of all firms that issue equity and all firms that issue neither equity nor debt. MA/BA is the ratio of market assets to book assets. Market leverage is the ratio of market debt to market assets. $t$-statistics are reported in parentheses. Prior stock return is the 1-year prior stock return, except in Hovakimian, Opler, and Titman (2001), in which case it is the 2-year prior stock return. In the first columns of Panel A and B, logit models with fixed year effects are used for the model-generated panel data. In the second columns, Fama-MacBeth methodology is used for the model-generated data. Logit regressions are first carried out year by year, and then the averaged coefficients and corresponding $t$-statistics are reported. The other columns report results from Marsh (1982) Table III, Hovakimian, Opler, and Titman (2001) Table 5, and Hovakimian, Hovakimian, and Tehranian (2004) Table 6 (for Panel A), and Table 8 (for Panel B).

Panel A. Equity vs. Debt

\begin{tabular}{lccccc}
\hline & Model FE & Model FM & Marsh(1982) & HOT(2001) & HHT(2004) \\
\hline Prior Stock Return & 9.94 & 9.7 & 1.026 & 0.542 & 0.093 \\
& $(31.74)$ & $(23.79)$ & $(4.0)$ & $(19.0)$ & $(3.8)$ \\
MA/BA & 10.8 & 10.0 & & 0.41 & 0.179 \\
& $(44.72)$ & $(40.27)$ & & $(13.4)$ & $(13.6)$ \\
Market Leverage & 14.6 & 13.9 & & & \\
& $(41.07)$ & $(47.02)$ & & & \\
Other Control Variables & No & No & Yes & Yes & Yes \\
Fixed Year Effects & Yes & No & No & Yes & Yes \\
$R^{2}$ & 0.6596 & 0.6126 & 0.37 & 0.195 & 0.228 \\
N. of Equity Issuances & 9886 & 9983 & 349 & 2231 & 2082 \\
N. of Observations & 13278 & 13375 & 748 & 10123 & 12300 \\
\hline
\end{tabular}

Panel B. Equity vs. No-Issuance

\begin{tabular}{lccc}
\hline & Model FE & Model FM & HHT(2004) \\
\hline Prior Stock Return & 2.5 & 2.0 & 0.370 \\
& $(30.61)$ & $(29.88)$ & $(10.0)$ \\
MA/BA & 1.03 & 0.534 & 0.311 \\
& $(32.79)$ & $(22.70)$ & $(18.2)$ \\
Market Leverage & 1.85 & 1.1 & \\
& $(20.16)$ & $(17.14)$ & \\
Other Control Variables & No & No & Yes \\
Fixed Year Effects & Yes & No & Yes \\
$R^{2}$ & 0.1523 & 0.0366 & \\
N. of Equity Issuances & 10002 & 10002 & 2082 \\
N. of Observations & 45357 & 48118 & 23946 \\
\hline
\end{tabular}


Table 4: Prior and Posterior Abnormal Returns for Corporate Financing Events

This table reports the abnormal returns prior to and following various corporate financing events for the simulated panel data of the main model. The simulation generates a random sample of 1,000 firms for 70 years, following the optimal financing strategies of the main model. The first 20 years are excluded from the final panel data. The abnormal return of a firm is defined as the difference between the return of the firm and that of a match firm chosen in the same year of the event with the closest market-to-book ratio. The mean statistic is equal to the arithmetic average of the series of annual average abnormal returns for each cohort year. $t$-statistics are obtained by applying the Fama-MacBeth procedure to the time-series of annual average abnormal returns, and reported in parentheses.

\begin{tabular}{|c|c|c|c|}
\hline & Prior Abnormal Return & \multicolumn{2}{|c|}{ Posterior Abnormal Return } \\
\hline & 1-year & 3-year & 5-year \\
\hline \multicolumn{4}{|c|}{ Panel A. Leverage-Decreasing Events } \\
\hline \multirow[t]{2}{*}{ Equity Issuance } & 6.30 & -7.71 & -14.25 \\
\hline & $(38.02)$ & $(-27.07)$ & $(-39.66)$ \\
\hline \multirow[t]{2}{*}{ Debt Reduction } & 4.07 & -7.39 & -9.80 \\
\hline & $(12.12)$ & $(-10.68)$ & $(-10.22)$ \\
\hline \multirow[t]{2}{*}{ Cash Accumulation } & 3.13 & -3.30 & -7.05 \\
\hline & $(14.96)$ & $(-8.47)$ & $(-11.53)$ \\
\hline \multicolumn{4}{|c|}{ Panel B. Leverage-Increasing Events } \\
\hline \multirow[t]{2}{*}{ Equity Repurchase } & -9.36 & 10.99 & 21.69 \\
\hline & $(-82.85)$ & $(44.20)$ & $(66.66)$ \\
\hline \multirow[t]{2}{*}{ Debt Issuance } & -8.88 & 5.62 & 11.76 \\
\hline & $(-29.00)$ & $(9.26)$ & $(12.43)$ \\
\hline \multirow[t]{2}{*}{ Cash Reduction } & -1.09 & 6.32 & 10.94 \\
\hline & $(-2.96)$ & $(10.03)$ & $(13.11)$ \\
\hline
\end{tabular}


Table 5: Long-Run Performance of Firms that Issue or Repurchase Equity

This table compares the results of annual abnormal returns for equity issuances/repurchases in Loughran and Ritter (1995) and Ikenberry, Lakonishok, and Vermaelen (1995) with those in simulated panel data of the main model. The simulation generates a random sample of 1,000 firms for 70 years, following the optimal financing strategies of the main model. The first 20 years are excluded from the final panel data. The annual abnormal return of a firm is defined as the difference between the annual return of the firm and that of a match firm. The match firm in the simulated data is chosen in the same year of the event with the closest market-to-book ratio.

\begin{tabular}{cccccc}
\hline \multicolumn{5}{c}{$\begin{array}{c}\text { Event } \\
\text { Firms }\end{array}$} & $\begin{array}{l}\text { Match } \\
\text { Firms }\end{array}$ \\
\multicolumn{5}{c}{ Panel A. Equity-Issuing Firms } \\
\hline \multicolumn{5}{c}{ a. Loughran and Ritter (1995) Table III } \\
\hline Year 1 & 6.6 & 12.9 & -6.3 & -5.59 & 3561 \\
Year 2 & 0.1 & 12.3 & -12.2 & -12.24 & 3614 \\
Year 3 & 7.5 & 16.2 & -8.7 & -8.08 & 3496 \\
Year 4 & 9.1 & 17.7 & -8.6 & -7.35 & 3154 \\
Year 5 & 11.8 & 17.4 & -5.6 & -16.80 & 2805 \\
\hline & \multicolumn{5}{c}{ b. Model-Generated Panel Data } \\
\hline Year 1 & 7.03 & 9.05 & -2.01 & -12.34 & 9979 \\
Year 2 & 6.83 & 9.22 & -2.38 & -14.38 & 9753 \\
Year 3 & 7.04 & 9.01 & -1.96 & -11.69 & 9510 \\
Year 4 & 7.26 & 9.34 & -2.07 & -11.92 & 9279 \\
Year 5 & 7.52 & 8.99 & -1.45 & -7.98 & 9029 \\
\hline
\end{tabular}

Panel B. Equity-Repurchasing Firms

a. Ikenberry, Lakonishok, and Vermaelen (1995) Table 3

\begin{tabular}{llllcc}
\hline Year 1 & 20.80 & 18.76 & 2.04 & 1.85 & 1208 \\
Year 2 & 18.12 & 15.81 & 2.31 & 1.65 & 1188 \\
Year 3 & 21.77 & 17.18 & 4.59 & 3.09 & 1047 \\
Year 4 & 8.56 & 9.51 & -0.96 & -0.14 & 893 \\
\hline \multicolumn{5}{c}{ b. Model-Generated Panel Data } \\
\hline Year 1 & 10.39 & 7.52 & 2.87 & 24.66 & 38599 \\
Year 2 & 10.44 & 7.64 & 2.80 & 23.57 & 37779 \\
Year 3 & 10.39 & 6.45 & 3.91 & 31.87 & 37044 \\
Year 4 & 10.33 & 6.43 & 3.88 & 29.90 & 36243 \\
\hline
\end{tabular}


Table 6: Comparison between Zero-Leverage and Average Dividend-Payers

This table reports the comparison of the firm characteristics for zero-leverage dividend payers and average dividendpayers, both in an empirical panel data and in the simulated panel data. The empirical data runs from 1973 to 2002 for 30 years. In 1973, 1,000 firms with the longest appearance in COMPUSTAT are chosen. The final sample consists of all observations of these 1,000 firms between 1973 and 2002. To obtain the simulated data, a random sample of 1,000 firms over a span of 70 years is generated, following the optimal financing strategies of the main model. The first 20 years are then excluded from the final panel data.

\begin{tabular}{|c|c|c|c|c|}
\hline & Profitability & $\mathrm{Div} / \mathrm{BA}$ & Cash/BA & Nobs \\
\hline \multicolumn{5}{|c|}{ Panel A: Empirical Data } \\
\hline Zero-Leverage Sample & 0.19 & 0.04 & 0.15 & 2569 \\
\hline Total Sample & 0.14 & 0.02 & 0.03 & 30000 \\
\hline Difference $t$-stat & 20.68 & 17.16 & 40.31 & \\
\hline \multicolumn{5}{|c|}{ Panel B: Model-Generated Panel Data } \\
\hline Zero-Leverage Sample & 0.21 & 0.14 & 1.15 & 4456 \\
\hline Total Sample & 0.13 & 0.04 & 0.12 & 50000 \\
\hline Difference $t$-stat & 113.28 & 97.47 & 65.46 & \\
\hline
\end{tabular}


Table 7: Relationship of Profitability with Leverage

This table reports the results of univariate regressions of book or market leverage ratios on profitability, in the empirical data, and the simulated data for the benchmark model and the main model. The regressions are conducted in the Fama-MacBeth manner: OLS regressions are first carried out for each year; the average of the time-series of the regression coefficients and $R^{2}$ 's are then reported. $t$-statistics are computed from the time-series of the regression coefficients and reported in parentheses.

Panel A. Book Leverage as the Dependent Variable

\begin{tabular}{lccc}
\hline & Empirical & Benchmark & Main Model \\
\hline Constant & 0.271 & 0.249 & 0.772 \\
& $(40.82)$ & $(170.64)$ & $(68.37)$ \\
Profitability & -0.47 & 4.33 & -2.92 \\
& $(-10.23)$ & $(125.61)$ & $(-23.61)$ \\
$R^{2}$ & 0.0660 & 0.8757 & 0.4696 \\
$N$ & 17234 & 45517 & 48517 \\
\hline
\end{tabular}

Panel B. Market Leverage as the Dependent Variable

\begin{tabular}{lccc}
\hline & Empirical & Benchmark & Main Model \\
\hline Constant & 0.386 & 0.845 & 0.948 \\
& $(25.47)$ & $(502.41)$ & $(90.27)$ \\
Profitability & -0.934 & -1.48 & -4.55 \\
& $(-17.23)$ & $(-47.65)$ & $(-38.65)$ \\
$R^{2}$ & 0.1255 & 0.4515 & 0.7788 \\
$N$ & 17234 & 45517 & 48517 \\
\hline
\end{tabular}

